This text is a pre-print. The paging and layout may differ from the final publication. For the purpose of citation, please refer to the publisher's version: Journal of Medieval History, 46.1 (2020) 23-49.

\title{
The Value of Status: Monetary Penalties in the Charters from León (854-1037)
}

\author{
aÁlvaro Carvajal Castro and ${ }^{\mathrm{b} J u l i o ~ E s c a l o n a ~}$ \\ ${ }^{a}$ Departamento de Geografía, Prehistoria y Arqueología, Universidad del País Vasco / Euskal Herriko \\ Unibertsitatea, Vitoria-Gasteiz, Spain. Grupo de Investigación en Arqueología Medieval, \\ Patrimonialización y Paisajes Culturales (código IT1193-19).
}

${ }^{b}$ Instituto de Historia, Centro Superior de Investigaciones Científicas, Madrid, Spain

Received: 11 July 2018

Accepted: 28 November 2018

For many regions of early medieval Europe, documents recording operations such as sales and pious donations, or contracts and judicial affairs, are perhaps the main window onto the inner workings of society. Charters - as they are commonly termed - represent a documentary culture that is strikingly homogeneous, notwithstanding regional traditions and countless minor variations across time and space. Much of this overall homogeneity has its roots in a common Roman heritage, as is apparent not only in the legal notions upon which they draw, but also in their structure, clauses and formulas. ${ }^{1}$ Over many

E-mail: carvajalcastro@gmail.com; julio.escalona@cchs.csic.es Postal addresses: Office 2.4, Centro de Investigación Micaela Portilla (UPV/EHU), C/Justo Vélez de Elorriaga, 1, 01006 Vitoria-Gasteiz, Spain; Office 2E15, Instituto de Historia, Centro de Ciencias Humanas y Sociales-CSIC, C/ Albasanz 26-28, 28037 Madrid, Spain

${ }^{1}$ The following abbreviations are used in this paper: C: Gonzalo Martínez Díez, ed., Colección documental del monasterio de San Pedro de Cardeña (Burgos: Caja de Ahorros y Monte de Piedad del Círculo Católico de Obreros de Burgos, 1998); Castañeda Ángel Rodríguez González, ed., El tumbo del monasterio de San Martín de Castañeda (León: Centro de Estudios e Investigación San Isidoro, 1973); Cel: Emilio Sáez and Carlos Sáez, eds. Colección diplomática del monasterio de Celanova (842-1230). 3 vols. (Alcalá de Henares: Universidad de Alcalá, 1996-2006); Eslonza: José Manuel Ruiz Asencio and Irene Ruiz Albi, eds., Colección documental del Monasterio de San Pedro de Eslonza, vol. 1: 912-1300 (León: Centro de Estudios e Investigación San Isidoro, 2007); Froncea: Cartulary of San Miguel de Froncea (unpublished), Oviedo, Biblioteca Universitaria de Oviedo, MS M. 456; Li: Emilio Sáez, ed. Colección documental del archivo de la Catedral de León (775-1230), vol. 1: 775-952 (León: Centro de Estudios e Investigación San Isidoro, 1987); Lii: Emilio Sáez and Carlos Sáez, eds., Colección documental del archivo de la Catedral de León (775-1230), vol. 2: 935-985 (León: Centro de Estudios e Investigación San Isidoro, 1987); Liii: José Manuel Ruiz Asencio, ed., Colección documental del archivo de la Catedral de León (775-1230), vol. 3: 986-1031 (León: Centro de Estudios e Investigación San Isidoro, 1987); Liv: José Manuel Ruiz Asencio, ed., Colección documental del archivo de la Catedral de León (775-1230), vol. 4: 1032-1109 (León: Centro de Estudios e Investigación San Isidoro, 1987); Leg. Visig.: Karl Zeumer, ed. Lex Wisigothorum. Monumenta Germaniae Historica, Leges nationum Germanicarum, 1 (Hannover: Hahn, 1902); OD: José Antonio Fernández Flórez and Marta Herrero de la Fuente, eds., Colección documental del monasterio de Santa María de Otero de las Dueñas, vol. 1: 854-1108 (León: Centro de Estudios e Investigación San Isidoro, 1999); Si: José M. ${ }^{a}$ Mínguez, Colección Diplomática del Monasterio de Sahagún (siglos IX y XI) (León: Centro de Estudios e Investigación San Isidoro, 1976); Sii: Marta Herrero de la Fuente, Colección Diplomática del Monasterio de Sahagún (857-1300), vol. 2: 1000-1073 (León: Centro de Estudios e Investigación San Isidoro, 1988); SMillan: Becerro Galicano Digital 
decades, historians and diplomatists have produced a vast body of scholarship on the diplomatic and legal intricacies of this documentation. More recently, however, the focus of attention has shifted towards its production, preservation and use as means of communication and instrument of power. ${ }^{2}$ This not only provides us with new avenues to explore early medieval social relationships, but also with an opportunity to reflect upon the very material that makes such explorations possible.

One widespread feature of early medieval charters are sanction clauses. ${ }^{3}$ They consist of a series of penalties aimed at deterring any breach of the terms recorded in the charter. Depending on the authority to which they appeal, two different types can be distinguished: 'spiritual' and 'secular'. Spiritual sanctions invoke divine intervention by threatening whoever may challenge the charter with punishments that can be both physical - such as illness and death - and spiritual, whether in this life - e.g. excommunication - or beyond - e.g. eternal damnation. They vary considerably: some are very simple, others have highly sophisticated provisions full of religious references. While they do not appear at all in some charter traditions, in others, like that of AngloSaxon England, they are the only sanctions used. ${ }^{4}$ Secular sanctions, on the other hand, appeal - explicitly or implicitly - to some sort of worldly authority, and have a distinct economic character: corporal punishment and enslavement are only exceptionally considered. ${ }^{5}$ Secular sanctions may include two types of provisions: firstly, compensation

(www.ehu.eus/galicano) (Accessed 7 November 2018); Sobrado: Pilar Loscertales, Tumbos del monasterio de Sobrado de los Monjes (Madrid: Ministerio de Cultura, Dirección General del Patrimonio, Archivos y Museos, 1976); TCel: José M. Andrade Cernadas, Marta Díaz Tie and Francisco Javier Pérez Rodríguez, O tombo de Celanova. Estudio introductorio, edición e índices (ss. IX-XII) (Santiago de Compostela: Consello da Cultura Galega, 1995); Toribio: Luis Sánchez Belda, Cartulario de Santo Toribio de Liébana (Madrid: Patronato Nacional de Archivos Históricos, 1948). Unless stated otherwise, references to published charters are given by the abbreviation of the edition followed by the piece's number in the edition and the year of the charter's creation.

The classic analysis is Peter Classen, 'Fortleben und Wandel spätrömischen Urkundenwesens im frühen Mittelalter', in Recht und Schrift im Mittelalter, ed. Peter Classen (Sigmaringen: Thorbecke, 1977), 13-54.

${ }^{2}$ See, among others, Brigitte Bedos-Rezak, 'Diplomatic Sources and Medieval Documentary Practices: An Essay in Interpretive Methodology', in The Past and Future of Medieval Studies, ed. John van Engen (Notre Dame: University of Notre Dame Press, 1994), 313-43; Warren Brown and others, eds., Documentary Culture and the Laity in the Early Middle Ages (Cambridge: Cambridge University Press, 2012); Karl Heidecker, ed., Charters and the Use of the Written Word in Medieval Society (Turnhout: Brepols, 2000); Jonathan Jarrett and Allan Scott McKinley, eds., Problems and Possibilities of Early Medieval Charters (Turnhout: Brepolds, 2013); Adam Kosto and Anders Winroth, eds., Charters, Cartularies and Archives. The preservation and Transmission of Documents in the Medieval West (Toronto: Pontifical Institute of Mediaeval Studies, 2002); Peter S. Barnwell and Marco Mostert, eds., Political Assemblies in the Earlier Middle Ages (Turnhout: Brepols, 2003); Marie-José Gasse-Grandjean and Benoit-Mitchel Tock, eds., Les actes comme expression du pouvoir au haut moyen âge: actes de la table ronde de Nancy, 26-27 novembre 1999 (Turnhout: Brepols, 2003); Julio Escalona and Hélène Sirantoine, eds., Chartes et cartulaires comme instruments de pouvoir. Espagne et Occident chrétien (VIIIe-XIIe siècles) (Toulouse: Editions Méridiennes, 2013).

${ }^{3}$ For a diplomatic description, see Arthur Giry, Manuel de diplomatique, 2nd edn. (Paris: Félix Alcan, 1925), 562-7, and more specifically Joachim Studtmann, 'Die Pönformel der mittelalterlichen Urkunden', Archiv für Urkundenforschung 12 (1932): 251-374. More relevant for this study is Francisco José Mattoso, 'Sanctio (875-1100)', Revista Portuguesa de História. Homenagem ao Doutor Paulo Merêa, vol. II, 13 (1971): 299-338.

${ }^{4}$ Sarah Hamilton, 'Remedies for 'Great Transgressions': Penance and Excommunication in Late AngloSaxon England', in Pastoral Care in Late Anglo-Saxon England, ed. Francesca Tinti (Woodbridge: Boydell Press, 2005), 100-2; see also Petra Hofmann, 'Infernal Imagery in Anglo-Saxon Charters' (Ph.D. diss., University of St Andrews, 2008), 7 and 30.

${ }^{5}$ On penal enslavement, see Alice Rio, Slavery after Rome, 500-1100 (Oxford Oxford University Press, 2017), 42-74. 
aimed at offsetting the damage caused or intended to be caused, usually through the restitution of a multiple of the value of the intended damage; and secondly, monetary penalties, in the form of a payment to a certain authority. ${ }^{6}$ A charter from the cartulary of San Pedro de Cardeña (Burgos) recording the donation of a piece of arable land (serna) dated to 915 provides an excellent example of how the different types of sanctions and provisions were combined:

[Sanction clause:] If anyone in his right mind, which we hardly believe possible, should dare to oppose you for this cause, whether it be myself or my grandchildren, or any other man, noble or non-noble, [Spiritual sanction:] in the first place, let the wrath of almighty God fall upon him and let him share Hell with Judas, who betrayed the Lord, and be alien to the faith of Christ and let the earth not receive his body. [Secular sanction; fine:] And further, as a secular penalty, let him pay four pounds of gold to the royal authority, [Secular sanction; compensation:] and let him give you twice this serna. ${ }^{7}$

Given their vividness, it is hardly surprising that spiritual clauses have attracted most attention. By studying their eschatological imagery and the characters and biblical scenes that appear as referents for the curses, historians have used them as gateways into the world of medieval beliefs and notions of justice, judgement and punishment. ${ }^{8}$ The changing balance between secular and spiritual clauses, as well as the identities of the potential recipients of the fines, have been interpreted as indicative of transformations in the frameworks of justice and of the varying weight that lay and ecclesiastical authorities enjoyed over time. ${ }^{9}$ Monetary penalties, by contrast, have usually been dismissed as dry, repetitive and idiosyncratic - even as a product of scribal whim. Certainly the payments they foresee tend to vary enormously, from apparently 'reasonable' figures to absolutely exorbitant ones, out of all proportion to the value of the goods transferred. This has driven scholars to dismiss them as having a primarily symbolic character, as if they had no bearing on social practices and relationships. ${ }^{10}$ This needs qualifying. On the one hand, monetary penalties were not merely theoretical. The Leonese charters that are the basis of this article contain several examples that suggest that, even when not actually paid,

\footnotetext{
${ }^{6}$ Wendy Davies, Windows on Justice in Northern Iberia, 800-1000 (Abingdon: Routledge, 2016), x.

${ }^{7}$ C8 (915): 'Quod si quis sane, quod fieri minime credimus, pro id uos inquietare presumpserit tam ego quam aut neptis meis, nobilis an ignobilis, aut quisliuet homo, in primis ira Dei omnipotentis super eam ueniat et cum Iuda, qui Dominum tradidit, participium in infernum abeat et extraneus sit a fide Christi, et terra corpus suum non recipiat. Et insuper damna secularia IIII libras aureas regia potestas inferat, et simile autem serna dupplata uobis reddat; scriptura firmis permaneat.'

${ }^{8}$ Lester K. Little, 'La morphologie des malédictions monastiques', Annales. Économies, Sociétés, Civilisations 34, no. 1 (1979): 43-60; Lester K. Little, Benedictine Maledictions. Liturgical Cursing in Romanesque France (Ithaca, NY: Cornell University Press, 1993); Lester K. Little, 'Anger in Monastic Curses', in Anger's Past: The Social Uses of an Emotion in the Middle Ages, ed. Barbara H. Rosenwein (Ithaca, NY: Cornell University Press, 1998), 9-35. For an exhaustive historiographical review, see François Bougard, 'Jugement divin, excommunication, anathème et malédiction: la sanction spirituelle dans les sources diplomatiques', in Exclure de la communauté chrétienne: sens et pratiques sociales de l'anathème et de l'excommunication (IVe-XIIe s.), eds. Geneviève Bührer-Thierry and Stéphane Gioanni (Turnhout: Brepols, 2015), 215-38.

${ }^{9}$ Mattoso, 'Sanctio', 328-32; Leticia Agúndez, 'Memoria y cultura en la documentación del monasterio de Sahagún: la respuesta de las fórmulas "inútiles” (904-1230)', Anuario de Estudios Medievales 40, no. 2 (2010): 886-7.

${ }^{10}$ Jeffrey A. Bowman, Shifting Landmarks. Property, Proof, and Dispute in Catalonia around the Year 1000 (Ithaca, NY: Cornell University Press, 2004), 193-4; Giry, Manuel de diplomatique, 567; Little, 'La morphologie des malédictions monastiques', 47; Mattoso, 'Sanctio', 323; Michel Zimmermann, Écrire et lire en Catalogne (IXe-XIIe siècle). 2 vols. (Madrid: Casa de Velázquez, 2003), 1: 365, 369, 378.
} 
extremely high fines worked as leverage to put the rival party in a weaker negotiating position should they breach the deed. ${ }^{11}$ Symbols, on the other hand, are powerful factors in social interactions. Even if monetary penalties do not reflect an economic assessment of the transaction's import, this does not mean that their use was merely whimsical or irrational. They still should 'make sense' in their social context. The question, therefore, is: if they had indeed a symbolic character, then what did they symbolise?

In order to answer this question, we must situate monetary penalties within their diplomatic and social contexts. The production of charters required specialised skills, as did the process of choosing the appropriate formulae and legal technicalities upon which their real effectiveness depended. Such abilities, long regarded as the exclusive competence of ecclesiastical centres, are increasingly detected in secular lay contexts, even if the actual scribes were mostly clerics. ${ }^{12}$ Extant formularies show that there was a range of suitable writing conventions for specific types of business. ${ }^{13}$ Indeed, as is apparent in the records that have been preserved, to a great extent it was seemingly the nature of the legal affair in question that determined the diplomatic shape of a charter. Throughout Europe, the bulk of extant charters are records of property transfers - sales, donations and, to a lesser extent, exchanges. Despite cases of ambiguity in form and content, ${ }^{14}$ a strong conceptual distinction between donations and sales is apparent. The difference is evident in form, content and language, and affected the use of sanction clauses as well. For instance, spiritual sanctions are rare in sales and exchanges but frequent in donations. ${ }^{15}$ Records of disputes are less abundant than sales and donations, though many of them concern property transfers. Monetary penalties were used in records of dispute for a variety of purposes, from seeking compliance with the proceedings, to securing the sentence or the agreement reached. However, there is again a significant grey

\footnotetext{
11 Álvaro Carvajal Castro, 'Secular Sanctions and Sales in Early Medieval León (9th-11th c.): Beyond Diplomatic Practice', Al-Masāq 29, no. 2 (2017): 159-64.

12 Brown and others., Documentary Culture and the Laity. In regions like northern Iberia, scribes were mainly clerics - including local priests - but in others there were also lay scribes: cf. Wendy Davies, 'Local Priests and the Writing of Charters in Northern Iberia in the Tenth Century', in Chartes et cartulaires, eds. Escalona and Sirantoine, 29-43; and Charles West, 'Meaning and Context: Moringus the Lay Scribe and Charter Formulation in late Carolingian Burgundy', in Problems and Possibilities of Early Medieval Charters, eds. Jarret and McKinley, 71-87.

${ }^{13}$ On formularies, see Alice Rio, Legal Practice and the Written Word in the Early Middle Ages: Frankish Formulae, c.500-1000 (Cambridge: Cambridge University Press, 2009); Alice Rio, 'Les formulaires et la pratique de l'écrit dans les actes de la vie quotidienne', Médiévales (special issue: Pratiques de l'écrit, eds. É Anheim and P. Chastang) 56 (2009): 11-22; Sebastien Barrett, 'Les actes écrits comme instruments de pouvoir: la contribution des formulaires', in Chartes et cartulaires, eds. Escalona and Sirantoine, 87-99.

${ }^{14}$ Wendy Davies, 'When Gift is Sale: Reciprocities and Commodities in Tenth-Century Christian Iberia', in The Languages of Gift in the Early Middle Ages, eds. Wendy Davies and Paul Fouracre (Cambridge: Cambridge University Press, 2010), 216-37.

${ }^{15}$ On the implications of different types of land transfers, see Wendy Davies and Paul Fouracre, eds., Property and power in the Early Middle Ages (Cambridge: Cambridge University Press, 1995); Les transferts patrimoniaux en Europe occidentale, VIIIe-Xe siècle (I). Actes de la table ronde de Rome, 6, 7 et 8 mai 1999, published as Mélanges de l'École Française de Rome. Moyen Âge 111, no. 2 (1999); Laurent Feller and Chris Wickham, Le marché de la terre au moyen âge (Rome: École française de Rome, 2005); Davies and Fouracre, eds., Languages of Gift. See also the remarks on the similarities between sales and exchanges in Italy in François Bougard, 'Commutatio, cambium, viganeum, vicariatio: l'échange dans l'Italie des VIIIe-XIe siècles', in Tauschgeschäft und Tauschurkunde vom 8. bis zum 12. Jahrhundert / L'acte d'échange, du VIIIe au XIIe siècle, eds. Irmgard Fees and Philippe Depreux (Cologne: Böhlau Verlag, 2010), 65-98. On the use of different sanction clauses in sales and donations, cf. Bougard, 'Jugement divin', 225; Jonathan Jarrett, 'The Anger of St Peter: The Effects of Spiritual Sanctions in Early Medieval Charters of Donations', unpublished paper presented at the 53rd Summer Meeting of the Ecclesiastical History Society, University of Sheffield (22-24 July 2014), online: http://eprints.whiterose.ac.uk/90085/ (accessed 7 November 2018).
} 
zone, because not a few standalone property transfers can be seen to derive, explicitly or implicitly, from disputes, as in the case of repossessions, confiscations, transfers representing compensations or fines, and so on.

Perhaps more importantly, historians are increasingly aware that land transfers and their eventual commitment to writing were part of ongoing processes of social interaction that took place at every scale, from the highest political spheres to the local worlds of ordinary people. At the most basic, their legal effectiveness was guaranteed by the participation of the intervening parties and a number of witnesses, who could be called upon later to confirm the deed if need be. ${ }^{16}$ Such events, however, could involve a larger number of people, both lay and ecclesiastic, for whom they provided a stage for displaying their social position and relationships. They were carried out according to structured proceedings, comprised of gestures and speeches that embedded shared virtues and values that the wider audience would anticipate and recognise. Should the transaction be committed to writing - which was not always the case - the public reading of the dispositions and the collection of testimonies from the witnesses would make an even greater impact on the audience's memory. ${ }^{17}$ Now, precisely because the attendees were familiar with the procedure and the formulae employed, including the warnings about the awful punishments that awaited those who attempted to breach the deed, they would have been quick to detect any variation and infer meaning from it, ultimately incorporating it into their account of the event. ${ }^{18}$ Any modification, including the expression of monetary penalties, could thus be incorporated into a shared public discourse. From this perspective, land transfers and charter-making cannot only be regarded as social performance entailing the enactment of particular social practices in a meaning-laden framework. They can also be said to have a performative dimension, in that the messages conveyed had the capacity to both reproduce and transform the actors' mental representations of the social landscape and with it condition their interactions and relationships. ${ }^{19}$

The fact that charters are performative and context dependent poses serious problems when considering features as variable as monetary penalties. Exhaustive contextual analyses of a document, or a group of inter-related documents, can exploit the richness of these sources and reveal the intricacies of individual cases. However, in order to unveil the principles that governed charter-making generally, a different approach is needed. Albeit at the cost of disregarding the peculiarities of individual documents, large charter collections can be approached through quantitative analysis of variability within shared features. However, to do so, particularly given the regional diversity of scribal traditions and practices, as well as the specificities of the different social contexts in which charters were produced, the research must be undertaken on a sufficiently broad

\footnotetext{
${ }^{16}$ On witnesses, see Benoit-Mitchel Tock, Scribes, souscripteurs et témoins dans les actes privés en France (VIIè - début XIIè siècle) (Turnhout: Brepols, 2005), 244-70. For León, see a thorough, quantified discussion in Graham Barrett, 'The Written and the World in Early Medieval Iberia' (D.Phil. diss., University of Oxford, 2015), 109-19. The authors thank G. Barrett for access to the text of his dissertation. ${ }^{17}$ Brigitte Miriam Bedos-Rezak, When Ego was Imago. Signs of Identity in the Middle Ages (Leiden: Brill, 2011), 19-20.

${ }^{18}$ Cf. Robin Chapman Stacey, Dark Speech. The Performance of Law in Early Ireland (Philadelphia: University of Pennsylvania Press, 2007), 118-29.

${ }^{19}$ For a classic study on the performative character of language, see J.L. Austin, How To Do Things with Words (Oxford: Clarendon Press, 1962). The performative dimension of Carolingian royal diplomas is emphasised by Geoffrey Koziol, The Politics of Memory and Identity in Carolingian Royal Diplomas: The West Frankish Kingdom (840-987) (Turnhout: Brepols, 2012), 17-62. However, non-royal charters were no less performative, in their own context; see Rosemund McKitterick, The Carolingians and the Written Word (Cambridge: Cambridge University Press, 1989), 91-2, and Bedos-Rezak, When Ego was Imago, 17-22.
} 
geographical scale. Thereafter, the same procedure can be tested on other regions and the results may be further refined through more contextual studies.

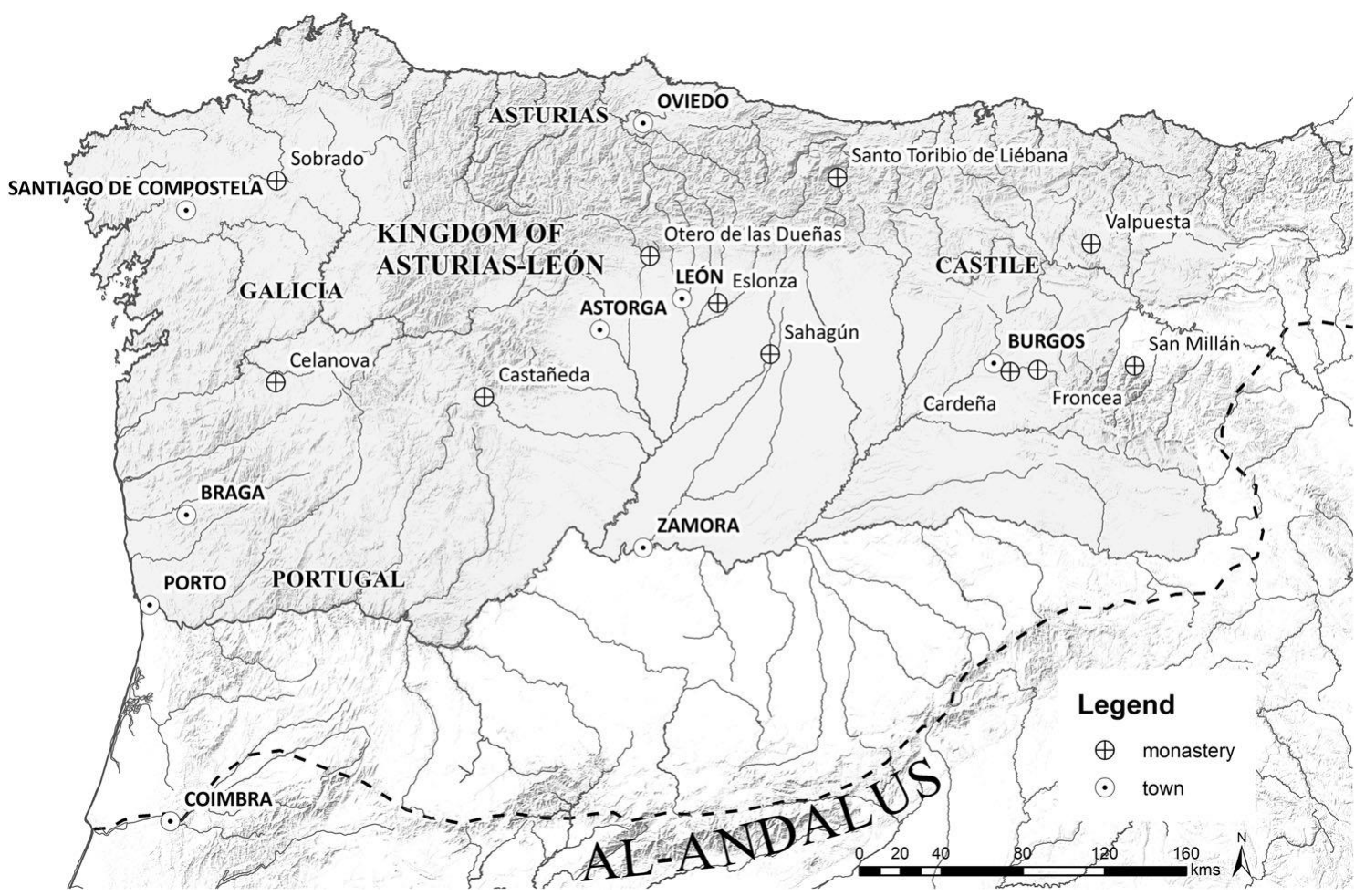

Figure 1: North-west Iberia in the tenth century. Source: Authors.

\section{Monetary penalties in the Leonese charters}

This article studies two specific features of monetary penalties: the amounts at which they were set and the accounting units in which they were expressed, in the extant charters from the region of León, in the north-west of the Iberian Peninsula, from c.850 to 1038 (Figure 1). The corpus, a total of 2009 charters, essentially consists of records of sales and donations, and, to a lesser extent, of disputes and exchanges (Figure 2). ${ }^{20}$ Their chronological distribution and geographical range are remarkably uneven throughout the period. They only become relatively abundant in the late ninth century, followed by a dramatic increase in the tenth century. The corpus has a strong ecclesiastical bias, as most charters were produced and preserved in monastic and episcopal centres, although traces of lay archives have been detected. ${ }^{21}$ Not all charters contain sanction clauses; however, some of them have been transmitted incomplete in copies and may have lost them in the process, while others never had them to begin with. There are 1642 charters with sanction clauses, of which 1509 include secular sanctions. Pecuniary penalties occur in 539 charters, of which roughly one third are preserved as single sheets and the rest as cartulary copies - and some as both. It is this sub-group of 539 charters with monetary penalties that constitutes the base material for this study.

\footnotetext{
20 This total includes all published charters for the region, whether single sheets or cartulary copies, forgeries excluded. Individual documents written on the same parchment, as well as cartulary entries including more than one text, have been broken down (e.g. Si94, a record including excerpts from 12 different charters). A detailed list of all published charters can be found at the PRJ project database: http://prj.csic.es/ (Accessed 7 November 2018).

21 Adam Kosto, 'Sicut mos esse solet: Documentary Practices in Christian Iberia, c.700-1000', in Documentary Culture and the Laity, ed. Brown and others, 259-282.
} 


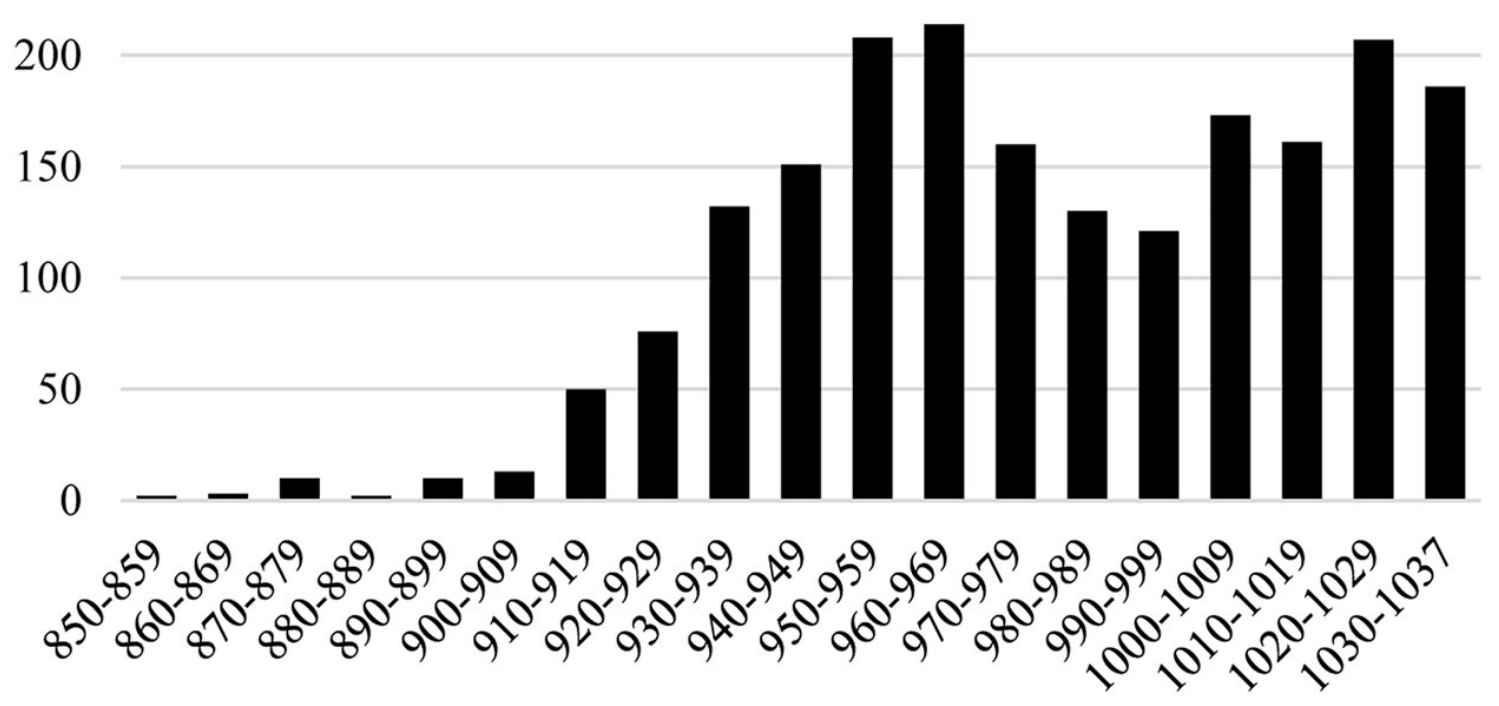

Figure 2: Chronological distribution of the extant charters from León (850-1037). Source: Authors.

Two preliminary questions must be addressed. First, since this sample, as with the whole corpus, is dominated by the large collections of the cathedral of León (291 charters) and the monastery of Sahagún (142 charters), could the scribal and archival practices at these two institutions have determined how monetary penalties were established? This is in practice not the case. The group from the cathedral of León group is not particularly homogeneous. Only 18 of its 291 charters were issued by, produced at, or granted to the cathedral. The rest come from other monastic houses including San Cosme y San Damián de Abellar, Santos Justo y Pastor de Ardón and Santiago de Valdevimbre, and there are also a few pieces recording transactions between lay parties. ${ }^{22}$ Thus, we should expect a mix of scribal practices in this collection. The Sahagún group, on the other hand, is more uniform, as 98 of its 142 charters are directly related to the monastery, while the rest come from other monastic and lay archives. However, in this case, as well as in that of Abellar - which also provides a numerically significant corpus - the charters show little consistency with regards to the formulae and the actual sanctions. ${ }^{23}$ Overall, it is exceptional to find compact blocks of defined scribal practice, such as that which occurs in a small group of donations to Santa Eulalia de Eslonza which repeat the same formula: 'conferat sanctis altaribus uestris auri libras quinas' ('he shall pay to your holy altars five

\footnotetext{
22 The breakdown of the León collection by provenance can be consulted at the PRJ database: http://prj.csic.es/ (accessed 7 November 2018). For similar points about the importance of analysing large collections of charters by their originating scriptoria, see Julio Escalona, 'La documentación de la Castilla condal: viejos problemas y nuevas perspectivas', in Mundos medievales. Espacios, sociedades y poder. Homenaje al Profesor José Ángel García de Cortázar y Ruiz de Aguirre, eds. Beatriz Arízaga Bolumburu and Jesús Ángel Solórzano (Santander: Universidad de Cantabria, 2012), 473-88 and Bedos-Rezak, When Ego was Imago, 15.

${ }^{23}$ For a sample of such variability, consider the following examples of donations made to these monasteries: for Sahagún, Si162 (959) (5 talents of gold), Si164 (959) (1 talent of gold), Si167 (959) (2 pounds of gold), Si196 (962) (10 pounds of gold); for Abellar, Lii321 (959) (1 pound of gold); Lii328 (4 pounds of gold); Lii346 (961) (2 talents of gold).
} 
pounds of gold'). ${ }^{24}$ The second question is whether the form in which these sanction clauses have come down to us could have been defined in the process of copying the charters into cartularies in the twelfth century and later. Fortunately, the number of singlesheet charters is sufficiently large to enable a comparison to be made with the cartulary versions. While cartulary makers sometimes made significant changes to their models, from spelling to the complete redrafting of whole passages, ${ }^{25}$ such operations rarely affected sanction clauses. ${ }^{26}$ The sample therefore is reasonably open to a quantitative analysis of monetary penalties.

\section{Currency, pricing and valuation}

Charters from north-west Iberia are rich in monetary expressions of price and valuation, ${ }^{27}$ despite the fact that no coinage was minted in the region during this period. Thus, rather than actual currency, such expressions represent money of account. Scholars have long attempted to explain its logic by comparing mentions of coins in the charters with the use of money in the Visigothic period and among the contemporary neighbours of the Leonese kingdom. ${ }^{28}$ In the Visigothic kingdom the reference monetary unit was the late Roman gold solidus, although only tremisses, worth one third of a solidus, were minted. These high-value gold coins were produced to fulfil the needs of state actors and institutions, such as collecting taxes and rewarding government servants. ${ }^{29}$ The archaeological evidence suggests that Roman copper coins remained in use for everyday small transactions and also that similar low value coins might have been minted occasionally, perhaps on the initiative of urban authorities rather than centrally. As for

\footnotetext{
${ }^{24}$ Eslonza8 (928). The only exception is Eslonza27 (957), though the value of the sanction is still five pounds. For a discussion of the formulaic practices in sanction clauses, see Jonathan Jarrett, 'Comparing the Earliest Documentary Culture in Carolingian Catalonia', in Problems and Possibilities of Early Medieval Charters, eds. Jarret and McKinley, 110-14.

${ }^{25}$ José A. Fernández Flórez, 'La huella de los copistas en los cartularios leoneses', in Orígenes de las lenguas romances en el reino de León: siglos IX-XIII (León: Centro de Estudios e Investigación San Isidoro, 2004), 159-228; Maurilio Pérez González, 'Originales y copias en la documentación medieval latina', Minerva: Revista de Filología Clásica 3 (1989): 239-66. See more widely Michel Parisse, 'Les cartulaires: copies ou sources originales?', in Les cartulaires, eds. Olivier Guyotjeannin, Laurent Morelle, and Michel Parisse (Paris: École Nationale des Chartes, 1993), 503-12; Laurent Morelle, 'Qu'est-ce qu'un acte original? Quelques remarques sur l'écrit documentaire des VIIe-XIIe siècles', Shigaku (The Historical Science) [Revue de l'Université Keio de Tokyo] 76, nos. 2-3 (2007): 89-120.

${ }^{26}$ Sahagún: Si255 (970) and Si256 (970); and Si330 and Si331 (986). León: Liii774 (1021), Liii792 (1022), Liii828 (1026). The changes consist of either adding a clause where there was none, or changing the amounts or units of the penalty, but almost never suppressing an existing sanction.

${ }^{27}$ e.g. 'accepimus de vos in precio VIII solidos de argento', Si292 (978); 'furtavi uno cavallo a fratre Stephano qui morabat in Sancta Eugenia valente LXa solidos', Si358 (998).

${ }^{28}$ Felipe Mateu y Llopis, 'Las clausulas penales pecuniarias de los documentos para la historia de las instituciones de León y de Castilla (siglos X-XIII)', Anuario de Historia del Derecho Español 23 (1953): 579-93; Felipe Mateu y Llopis, 'Talentum argenti y talenta auri. Del Evangelio de San Mateo a los diplomas hispanos anteriores a 1126', in Salvacion en la palabra. Targum, Derash, Berith: en memoria del profesor Alejandro Diez Macho, ed. Domingo Muñoz León (Madrid: Ediciones Cristiandad, 1986), 73548; Fátima Martín Escudero, Julio Miguel Martínez and Alberto J. Canto García, 'La circulación monetaria en el reinado de Alfonso III a través de las fuentes documentales', in MC Aniversario de la muerte de Alfonso III y de la tripartición del territorio del Reino de Asturias, eds. Alfonso García Leal, Ramón Gutiérrez González and Clara Elena Prieto Entralgo., Asturiensis Regni Territorium. Documentos y Estudios sobre el Período Tardorromano y Medieval en el Noroeste Hispano (Oviedo: Universidad de Oviedo, 2011), 157-205.

${ }^{29}$ Iñaki Martín Viso, 'Tributación y escenarios locales en el centro de la Península Ibérica: algunas hipótesis a partir del análisis de las pizarras "visigodas", Antiquité Tardive 14 (2006): 263-90; Eduardo Manzano Moreno, 'Moneda y articulación social en al-Andalus en época omeya', in Monnaies du haut moyen âge. Histoire et archéologie (Péninsule Ibérique - Maghreb, VIIe-XIe siècle), eds. Philippe Sénac and Sébastien Gasc (Toulouse: Méridiennes, 2015), 133-56.
} 
silver coins, the evidence for their circulation has not been definitively established. ${ }^{30}$ This picture changed after the Arab conquest in AD 711. Initially the new rulers issued high value gold coins - the so-called 'transitional solidi' as well as gold dinnärs - and lowvalue copper fulüs (singular fals) for small transactions. However, starting in the 740s the minting of fulūs declined while that of gold dīnārs stopped abruptly, only to be resumed in 929 with the proclamation of the caliphate by Abd al-Rahman III. The dinnarr remained the unit of account but silver dirhams quickly became the only money in circulation. ${ }^{31} \mathrm{~A}$ parallel shift to silver took place in the neighbouring Carolingian kingdom, where the silver solidus was adopted as the reference unit while only denarii worth $1 / 12$ of a solidus were struck. Carolingian coins occasionally appear in hoards from southern Iberia, but too few have been found to suggest Carolingian influence on the monetary system of AlAndalus. $^{32}$

By contrast, in north-west Iberia minting coins ceased altogether after 711. A few tenth-century charters hint at coins used in very specific areas, but this can hardly have been more than residual Visigothic pieces or occasional imports from al-Andalus or elsewhere. ${ }^{33}$ Although most people only rarely came into contact with coins themselves, currency units were widely used to estimate value or calculate payments in kind. ${ }^{34}$ Initially the reference was the traditional, gold-based standard of the Visigothic system, which survived in regions like Galicia and Cantabria into the tenth century. However, in the Duero plateau silver soon predominated as the reference metal, and by the tenth century it had become dominant across the entire north-west. ${ }^{35}$ Although C. SánchezAlbornoz attributed this to Carolingian influence, his hypothesis was weakened by the fact that charters from north-west Iberia mention neither silver denarii nor traces of the standard Carolingian equivalence of 12 denarii to the solidus and 20 solidi to the pound. ${ }^{36}$

\footnotetext{
${ }^{30}$ Compare the pioneering - though significantly out of date - study by Miquel Crusafont i Sabater, El sistema monetario visigodo: cobre y oro (Barcelona: Asociación Numismática Española, 1994), with the recent contributions of Ruth Pliego Vázquez, La moneda visigoda. 2 vols. (Sevilla: Universidad de Sevilla, 2009); Álvaro Fernández-Flores, Ruth Pliego-Vázquez, and Gabriel Carvajal-Mateos, 'Nuevos hallazgos de bronces visigodos en la provincia de Sevilla: una aproximación metrológica y de composición metálica', Journal of Archaeological Numismatics 2 (2013): 275-304.

${ }^{31}$ The nominal equivalence was initially 12, and later 8 dirhams to the dīnār, but the working equivalence could reach even 17 or 18 dirhams to the $\operatorname{din} \bar{a} r$, due to the low grade of silver. Manzano Moreno, 'Moneda y articulación social', 150-4.

32 Fátima Martín Escudero, 'Tesoros numismáticos. Mucho más que monedas acumuladas. Hallazgos monetarios de los emiratos dependiente e independiente', in Monnaies du Haut Moyen Âge, eds. Sénac and Gasc, 173-210.

${ }^{33}$ See Martín Escudero, 'Tesoros numismáticos', for a recent revision and mapping of coin finds from the Emirate period.

${ }^{34}$ Wendy Davies has suggested that in the tenth century, fragments of silver could occasionally be used in real transactions, but in very restricted areas: Wendy Davies, 'Sale, Price and Valuation in Galicia and Castile-León in the Tenth Century', Early Medieval Europe 11, no. 2 (2002): 164. Cuttings of silver coins occur in Andalusi hoards but have not been attested in the north-west so far. See Mark Blackburn, 'Money and Coinage', in The New Cambridge Medieval History, vol. 2: c.700-c.900, ed. Rosamond McKitterick (Cambridge: Cambridge University Press, 1995), 550-1.

${ }^{35}$ Claudio Sánchez-Albornoz, 'El precio de la vida en el reino asturleonés hace mil años', in Viejos y nuevos estudios sobre las instituciones medievales españolas, vol. 2 (Madrid: Espasa-Calpe, 1944), 809-52; Claudio Sánchez-Albornoz, 'La primitiva organización monetaria de León y Castilla', Anuario de Historia del Derecho Español 5 (1928): 302. In Cantabria tremisses are mentioned in Toribio2 (796) to Toribio27 (921). In León tremisses are mentioned in Li8 (876) but solidos de argenteos occur in Li9 (894) and argenteus in Li14 (899). In Galicia the tremisses was used as money of account throughout the tenth century: e.g. Cel45 (935); Cel152 (962); Cel254 (1001).

${ }^{36}$ Eduardo Manzano and Alberto Canto, 'The Value of Wealth: Coins and Coinage in Iberian Early Medieval Documents (9th-11th Centuries)', in Beyond Reconquista, eds. Robert Portass and Simon Barton (Leiden: Brill, Forthcoming). We thank the authors for access to the text of their unpublished paper. Cf.
} 
J. Gautier-Dalché has suggested looking to al-Andalus for influence here. ${ }^{37}$ This idea has been taken up recently by E. Manzano and A. Canto, who have argued convincingly that the solidus argenteus of the Leonese texts paralleled the Andalusian 'dinnar of dirhams' - that is, an amount of dirhams worth one dinār, the equivalence being 8 dirhams to the dina $\overline{a r}$ - and that the argenteus was equivalent to the dirham. Indeed, some Leonese charters record a working correspondence of eight to 10 argentei to the solidus. ${ }^{38}$ This is a credible explanation for the system of money of account reflected in north-west Iberian charters. That the move to a gold standard in the caliphate of Córdoba in c.929 left virtually no trace in the kingdom of León strongly suggests that by the early tenth century the northern interpretation of the Emirate's silver-based monetary system was firmly rooted in the region.

\section{The metals and units in monetary penalties}

Historians' understanding of the system of account underlying prices and valuation in north-west Iberia has recently advanced significantly, but monetary penalties lie beyond the scope of the analyses that have been undertaken. ${ }^{39}$ The first striking aspect of the monetary penalties of the Leonese charters is that they are expressed either in coins or in gold weight. The only unit of currency used in the León region was the silver solidus, even though in neighbouring areas, like Galicia, Cantabria and Castile, other units such as the silver denarius, the gold solidus and the silver mark appear sporadically. ${ }^{40}$ Gold, on the other hand, was measured either in talents or, more often, in pounds. ${ }^{41}$ Overall, weights in gold predominate, although the use of silver solidi increased in the first third of the eleventh century (Figure 3). This dichotomy is even more remarkable considering that no coins were struck in the kingdom at the time, and that all assessments employed solely units of silver currency.

Claudio Sánchez-Albornoz, 'Moneda de cambio y moneda de cuenta en el reino asturleonés', in Viejos y nuevos estudios, vol. 2: 880; Sánchez-Albornoz, 'La primitiva organización monetaria', 304-5.

37 Jean Gautier-Dalché, 'Du royaume asturo-léonais à la monarchie castillano-léonaise: une histoire monétaire singulière (VIIIe-IXe siècle)', in L'argent au moyen âge. Actes des congrès de la Société des historiens médiévistes de l'enseignement supérieur public, $28^{e}$ congrès, Clermont-Ferrand, 1997 (Paris: Publications de la Sorbonne, 1998), 77-92. The idea had been suggested by Felipe Mateu y Llopis, 'Sobre las hipótesis del oro asturleonés anterior al maravedí', Anuario de Historia del Derecho Español 18 (1947): 630-41.

${ }^{38}$ Manzano and Canto, 'Value of Wealth'.

${ }^{39}$ Davies, 'Sale, Price and Valuation'; Manzano and Canto, 'Value of Wealth'.

${ }^{40}$ A review of the different units used in monetary penalties in the charters from north-western Iberia can be found in Mateu y Llopis, 'Las clausulas penales pecuniarias'. See also Julio Mínguez Martínez, 'Moneda medieval en el Reino de León. Análisis de términos monetarios en la documentación del Archivo de la Catedral de León (711-1252)', Ab Initio, Núm. Ext. 1 (2011): 11-67. In Galicia there are references to denarii, Sobrado2 (955), and Sobrado7 (961); and gold solidi, Sobrado117 (1006), and TCel552 (1007). In Castile there are mentions of pounds of silver in Cardeña, C68 (950), and Froncea, ff 14r-v (976). Gold solidi appear in C36 (941), conceivably a scribal confusion when recording an exchange derived from a judicial process. They also appear in Cardeña, C34 (941), but this is a forgery apparently based on C36. Silver marks appear in one instance, SMillan321 (1006). None of these units appear in the charters from León.

${ }^{41}$ e.g. 'persolbat a parte fiscalia quinas auri libras', Si160 (958); 'in damnum persolbat auri talentum a parte regis', Si164 (959). This use is widely found throughout the charter corpus from northern Iberia from the mid-ninth century onwards: Martín Escudero, Miguel Martínez and Canto García, 'La circulación monetaria'. 


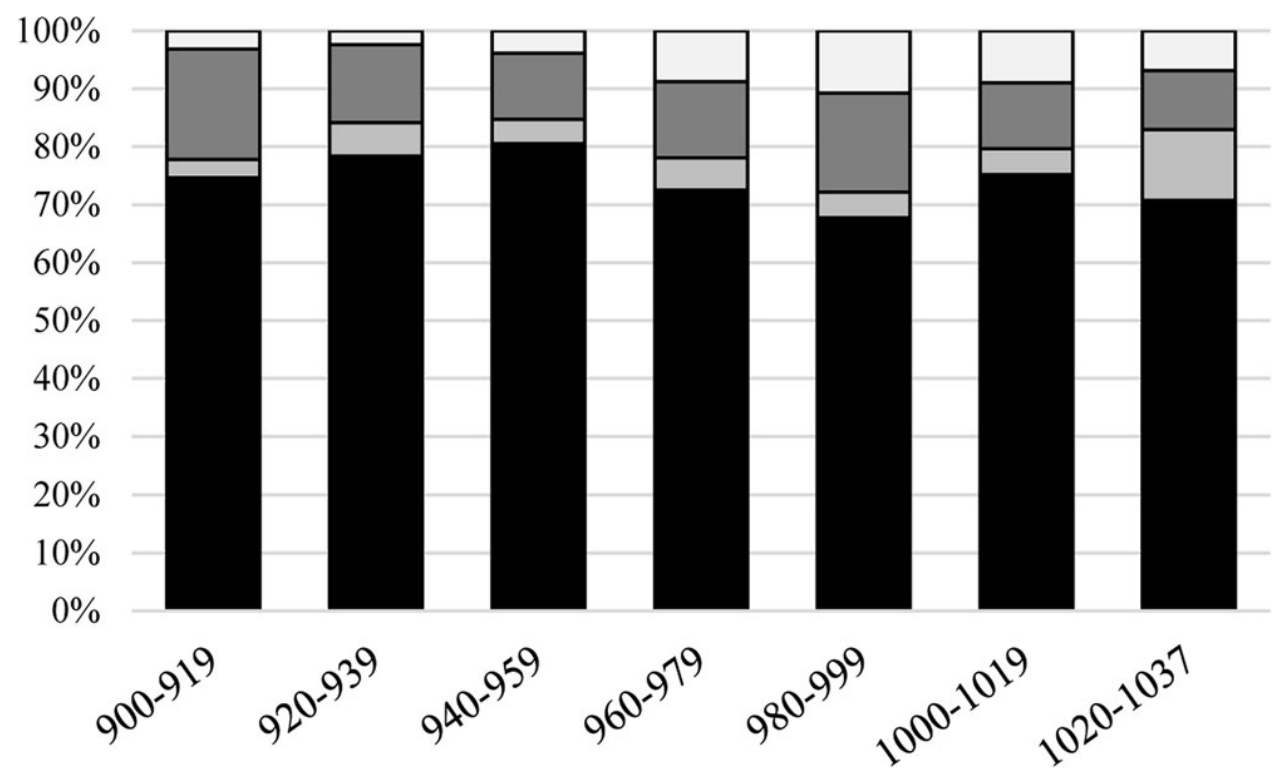

■o monetary penalty $\square$ Solidi $\square$ Pounds $\square$ Talents

Figure 3. Percentages of different units of account in monetary penalties, 900-1037. Source: Authors.

It is not easy to ascertain whether this pattern had been inherited from an earlier period. The diplomatic evidence for the Visigothic period comes down to a handful of fragments on parchment or slate, and four texts transmitted by way later copies. One such text written on slate mentions what could be a monetary sanction or compensation; ${ }^{42}$ all other mentions of coinage correspond either to prices or estimates of fiscal returns. ${ }^{43}$ However, the so-called Visigothic Formulae include two examples of royal diplomas with monetary penalties set in pounds of gold payable to the royal fiscus ${ }^{44}$ To widen the discussion, it is necessary to consider the evidence from the Visigothic laws, the so-called Liber iudicum or Liber iudiciorum. ${ }^{45}$ Interestingly, in these laws monetary penalties were also

\footnotetext{
${ }^{42}$ Isabel Velázquez Soriano, Las pizarras visigodas (Entre el latín y su disgregación. La lengua hablada en Hispania, siglos VI-VIII) (Real Academia Española - Fundación Instituto Castellano y Leonés de la Lengua, 2004), no. 92.

${ }^{43}$ Velázquez Soriano, Las pizarras visigodas, nos. 8, 13, 19, 40, 76, 92, 96, 102. There is an exceptional mention of a payment in gold ounces: no. 43. For the parchment fragments, see Anscari Manuel Mundó Marcet, Los diplomas visigodos originales en pergamino. Transcripción y comentario, con un regesto de documentos de la época visigoda (resumen de la tesis presentada para aspirar al grado de Doctor en Filosofía y Letras) (Barcelona: Universidad de Barcelona, 1974). The diplomatic evidence from the Visigothic period is brought together in Ángel Canellas López, 'De diplomática hispano-visigoda: colección documental', Revista de Historia Jerónimo Zurita 33-34 (1979): 251-418, but this must be handled with caution, since it mixes actual charters, formularies and legal texts. The four recently identified documents from the monastery of San Vicente de Asán (Huesca) have no pecuniary penalties, but one of them includes a royal exemption of the annual tax on a bishop's estate that is assessed at 50 [gold] solidi: Guillermo Tomás Faci and José Carlos Martín, 'Cuatro documentos inéditos del monasterio visigodo de San Martín de Asán (522-586)’, Mittellateinisches Jahrbuch 52, no. 2 (2017): doc. no. 2, p. 279.

${ }^{44}$ Juan Gil, 'Formulae Wisigothicae', in Miscellanea Wisigothica, ed. Juan Gil (Sevilla: Universidad de Sevilla, 1972), nos. V and XXIV. The collection of formulae appended to the ninth-century Silos Orational (London, British Library, Add. MS 30850, ffs. 96v, 99v and 98), which are often considered of Visigothic provenance, could equally be of a later date.

${ }^{45}$ Karl Zeumer, ed. Lex Wisigothorum. Monumenta Germaniae Historica, Leges nationum Germanicarum, 1 (Hannover: Hahn, 1902). This is a legal collection copied and issued by royal initiative. At least two different versions have been identified, but the earliest extant copies of this corpus date from the tenth century and must thus be handled with caution. See Manuel Cecilio Díaz y Díaz, 'La Lex Visigothorum y
} 
established in two ways, either by reference to a unit of coinage - the gold solidus - or to a unit of gold weight - the pound. Each was apparently associated with a different legal sphere. Penalties in pounds of gold were preferred as punishment for the breach of royal authority in particularly sensitive fields, such as the exercise of justice, ${ }^{46}$ the army ${ }^{47}$ and anti-Jewish legislation. ${ }^{48}$ The promulgation of royal edicts and other norms was sometimes reinforced with monetary penalties, and pounds of gold. ${ }^{49}$ Penalties in coinage, by contrast, were mainly used in the context of ordinary justice, either for offences incurred during judicial process ${ }^{50}$ or, more frequently, to punish crimes against people and property such as robbery, assault, homicide and trespass. There was, however, a grey zone between the two spheres: in cases of manslaughter the revenge of the kin could be avoided by payment of one pound of gold $;{ }^{51}$ and anyone who incited daughters, wives or widows to adultery or fornication had to compensate the father or husband with five pounds of gold. ${ }^{52}$ These provisions seem to draw an analogy between the authority of the king and that of the paterfamilias. For the rest, penalties in gold weight or in coin consistently separate the gravest offences (mainly against royal authority) from ordinary crimes subject to an assessment of damages.

Did a similar distinction apply to the Leonese charters, despite the shift from gold to silver coinage? This can be explored by checking the use of coin or weight of gold against the kind of legal business recorded in the charters. To this end, the 1642 charters with monetary penalties have been classified into three categories: donations, sales/exchanges and records of dispute. The process is far from straightforward and involves some fine judgement, especially regarding sale records that are formally presented as donations and vice versa. In these cases, the characterisation that the formulas used provides for the transaction has been prioritised over the context as it can be inferred from the charter, though some consideration has been given to the latter. The seven extant exchanges have all been classified as sales, despite notional differences between them, because of their low number and the apparent similarity in the use of sanction clauses in all cases. ${ }^{53}$ The donations include all records of grants or confirmations of grants, notwithstanding the specific vocabulary used. Records of dispute comprise all charters related to the settlement of conflicts and, more particularly, to the judicial sphere, such as placita and agnitiones, excluding those which on the basis of the

sus manuscritos. Un ensayo de reinterpretación', Anuario de Historia del Derecho Español 46 (1976): 163224.

${ }^{46}$ e.g. one pound of gold for whoever attempts to exercise justice in a territory for which he has not been appointed (Leg. Visig., II, 1, 18) or for whoever tries to move a cause after the 30 year statute of limitations has passed (Leg. Visig., X, 2, 3); two pounds of gold for noblemen who try to influence a judgement (Leg. Visig., II, 2, 8); three pounds for noblemen who ignore a royal summons to court (Leg. Visig., II, 1, 33); t10 pounds for judges who oppress the people unjustly (Leg. Visig., XII, 1, 2); or an exorbitant 30 pounds of gold for whoever uses any book of law other than the Liber iudiciorum (Leg. Visig., II, 1, 11).

${ }^{47}$ Especially in the so-called military laws of Ervig (e.g. Leg. Visig., IX, 2, 9).

48 The political relevance of anti-Jewish provisions is highlighted by their unusually high monetary penalties (Leg. Visig., XII, 3, 17; XII, 3, 17; XII, 3, 22).

49 Ángel Canellas López, Diplomática hispano-visigoda (Zaragoza: Institución Fernando el Católico, 1979), nos. 12, 34, 47 and 228.

${ }^{50}$ Such as those committed by judges and other judicial officers who neglect their duty or by individuals who ignore a summons or disrupt a hearing (Leg. Visig., II, 1, 19; II, 2, 2).

${ }^{51}$ Leg. Visig., VI, 4, 3; VI, 5, 3; VI, 5, 7; VI, 5, 12. See also Leg. Visig., VII, 3, 6; IX, 1, 21 and XI, 1, 8.

${ }^{52}$ Leg. Visig., III, 3, 11.

${ }^{53}$ Li153 (942); Li244 (952); Li245 (952); Si277 (974); Liii739 (1015); Liii778 (1021); Liv942 (1035). Cf. Wendy Davies, 'Exchange Charters in the Kingdom of Asturias-León, 700-1000', in L'acte d'échange, eds. Fees and Depreux, 471-90. 
formulas used in the document can be classified as sales and donations,${ }^{54}$ as well as sales and donations derived from dispute settlements. ${ }^{55}$

\begin{tabular}{|l|r|r|r|r|}
\hline Table 1. Types of business in charters with sanction clauses \\
\hline & \multicolumn{2}{|c|}{$\begin{array}{c}\text { Charters with sanction } \\
\text { clauses }(\mathrm{n}=1642)\end{array}$} & \multicolumn{3}{c|}{$\begin{array}{c}\text { Charters with monetary } \\
\text { penalties }(\mathrm{n}=539)\end{array}$} \\
\hline Donations & 716 & $44 \%$ & 418 & $78 \%$ \\
\hline Sales/exchanges & 854 & $52 \%$ & 65 & $12 \%$ \\
\hline Records of disputes & 72 & $4 \%$ & 56 & $10 \%$ \\
\hline
\end{tabular}

Source: Authors.

Sales and exchanges

Judicial Records

Donations
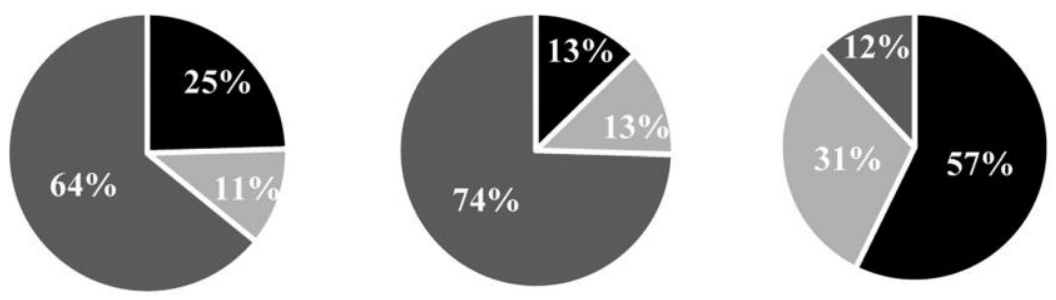

- Pounds $=$ Talents $\quad$ Solidi

Figure 4. Percentages of different units of account by type of document, 900-1037. Source: Authors.

On the basis of this classification, a clear pattern emerges (Table 1). Monetary penalties occur in only $7.6 \%$ of all sales and exchanges with sanction clauses, but are far more abundant in donations (58.4\%). Likewise, the majority of records of dispute also have monetary penalties $(77.8 \%)$, although it should be noted that the dataset is significantly smaller. Furthermore, the type of legal business (Figure 4) marks a clear distinction between the use of weights in gold - pounds and talents - which prevail in donations $(88 \%)$, and that of silver solidi, which are dominant in sales/exchanges $(64 \%)$ and records of dispute (74\%). The dominant pattern is clear, but the less than perfect correlation might reflect the ambiguities in the categories noted above. In some cases it was probably the type of transaction recorded, rather than the formulae for expressing it, that may have determined the choice of unit of account for the monetary penalty. ${ }^{56}$ For example, the fact that a transaction resulted from a dispute might have inclined the choice of unit towards silver solidi, rather than to pounds or talents of gold. The rare use of silver solidi in donations may indicate that these cases resulted from disputes, a hypothesis that is an interesting starting point for future contextual analysis.

Silver coins and weights in gold belonged to different notional spheres, and there is no clear equivalence between their respective units. Even between units of gold alone, hints of a correspondence are only to be found on occasion. ${ }^{57}$ Thus, the amounts at which monetary penalties were set are best studied separately. Weights in gold range from 1 to

\footnotetext{
${ }^{54}$ On this and the previous remark, see Davies, Windows on Justice, 35-64; and Isabel Alfonso Antón, 'El formato de la información judicial en la Alta Edad Media peninsular', in Chartes et cartulaires, eds. Escalona and Sirantoine, 191-218.

55 OD1 (854); Liii711 (1013); Lii489 (982); Eslonza19 (945); Sii394 (1009). Cf. Davies, 'When Gift Is Sale'.

${ }^{56}$ Cf. Davies, 'When Gift Is Sale'.

${ }^{57}$ Five charters bear the formula 'conponat auri libras quinas trinas vel talenta': Si316 (983); Si329 (986); Liii571 (995); Liii580 (998); Liii627 (1002); but this correspondence is found nowhere else in the corpus.
} 
1000 pounds or 2000 talents, but the exorbitant figures are exceptional (Figure 5). Lower amounts, particularly in talents, tended to be the norm. Why scribes opted for one or the other end of the scale is not readily apparent, nor is it clear why the amounts are so variable in the lower range. The highest monetary penalty, 2,000 talents, occurs in the donation of a village and church to the monastery of Castañeda by an otherwise unremarkable priest. ${ }^{58}$ In contrast, a much higher status grant made by King Vermudo II to the cathedral of León bears a sanction of just one talent. ${ }^{59}$ As far as we have been able to determine, sanctions in gold resist any quantitative scaling. Rather, they appear to be as emphatic and hyperbolic as the spiritual sanctions with which they are frequently associated and thus their symbolism might perhaps be understood as another form of malediction. However, this cannot be explored in depth in this article and should be the matter of further research.
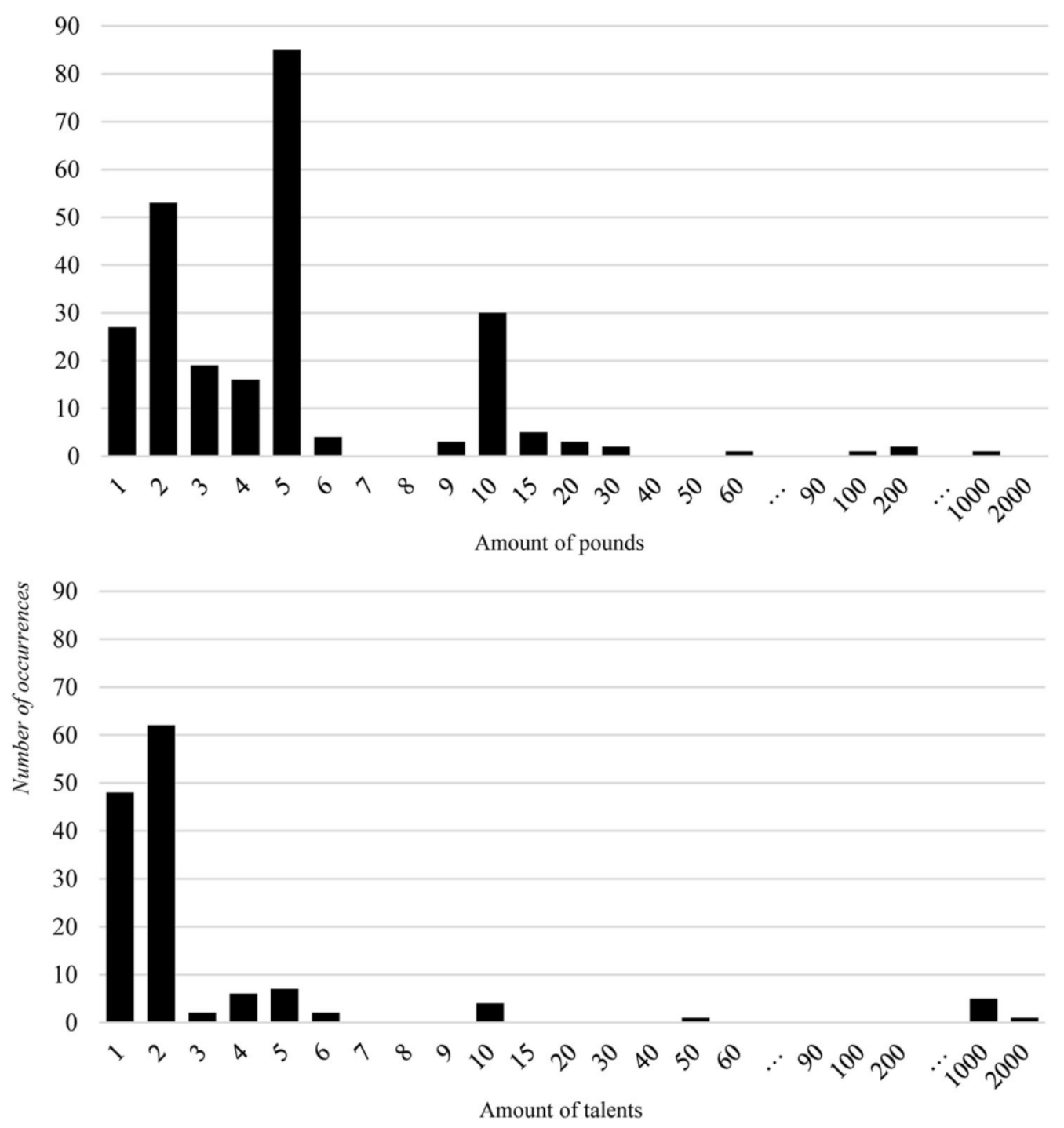

Figure 5. Level of penalties recorded in pounds and talents, 900-1037.

Source: Authors.

${ }^{58}$ Castañeda9 (968).

${ }^{59}$ Lii507 (985). 
Amounts in silver coinage exhibit an entirely different pattern (Figure 6). They tend to keep to multiples of 10 to 100 solidi, and then multiples of 100 up to 500 solidi, with peaks at 30, 100 and 500 solidi. By breaking this distribution down by type of legal business, further nuance emerges (Figure 7). While sales and records of dispute records do not exceed 500 solidi, donations have a wider range, reaching as high as 3000 solidi. In sales and records of dispute, monetary penalties have two peaks, a marked one at 100 solidi and a less marked one at 500 solidi. Conversely, the amounts employed in donations have a minor peak at 100 and a very prominent peak at 500 solidi, and in most cases lie within the range of 500 solidi or more.

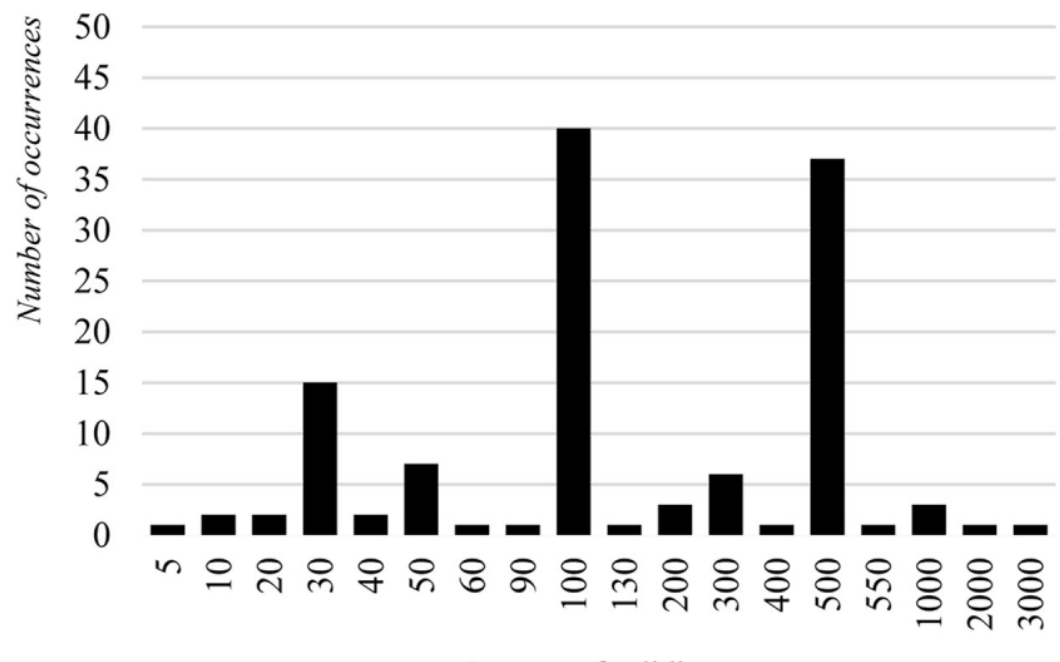

Amount of solidi

Figure 6. Level of penalties recorded in solidi, 900-1037. Source: Authors.

In Visigothic law, pounds of gold and solidi had clearly differentiated functions. Pounds of gold were preferred in matters concerning royal authority. This seems to be paralleled in the tenth-century Leonese charters by the association between penalties in gold and donations to the Church. Since the latter were addressed to God and the saints, ${ }^{60}$ it was logical to protect them not only with spiritual curses, but also with the kind of monetary penalties that were suitable for matters of the utmost importance. Perhaps the occasional use of pounds of gold in donations between lay parties might be understood as a way to emphasise the significance of the gift, because of the symbolic associations of gold. ${ }^{61}$ As for the silver solidus, despite the shift from gold to silver, it continued to be used in the judicial sphere and in secular affairs such as sales and exchanges, where it maintained a scale of valuation similar to the one employed in Visigothic law. The fact that silver solidi were used even when ecclesiastical houses were involved reinforces the idea that the nature of the business had a bearing on the choice of monetary penalty. This distinction, however, is not absolute, and the deviations from the norm are the subject of further research.

\footnotetext{
${ }^{60}$ Cf. Barbara H. Rosenwein, To Be the Neighbor of Saint Peter: The Social Meaning of Cluny's Property, 909-1049 (Ithaca, NY: Cornell University Press, 1989).

${ }^{61}$ e.g. OD1 (854), Si19 (920), OD30 (989), OD55 (1001), Eslonza34 (1032). On the significance of gift giving between lay parties, see Florin Curta, 'Merovingian and Carolingian Gift Giving', Speculum 81, no. 3 (2006): 671-99. A recent review of the literature on the gift in early medieval studies can be found in Arnoud-Jan Bijsterveld, Do ut des. Gift Giving, Memoria, and Conflict Management in the Medieval Low Countries (Hilversum: Uitgeverij Verloren, 2007).
} 

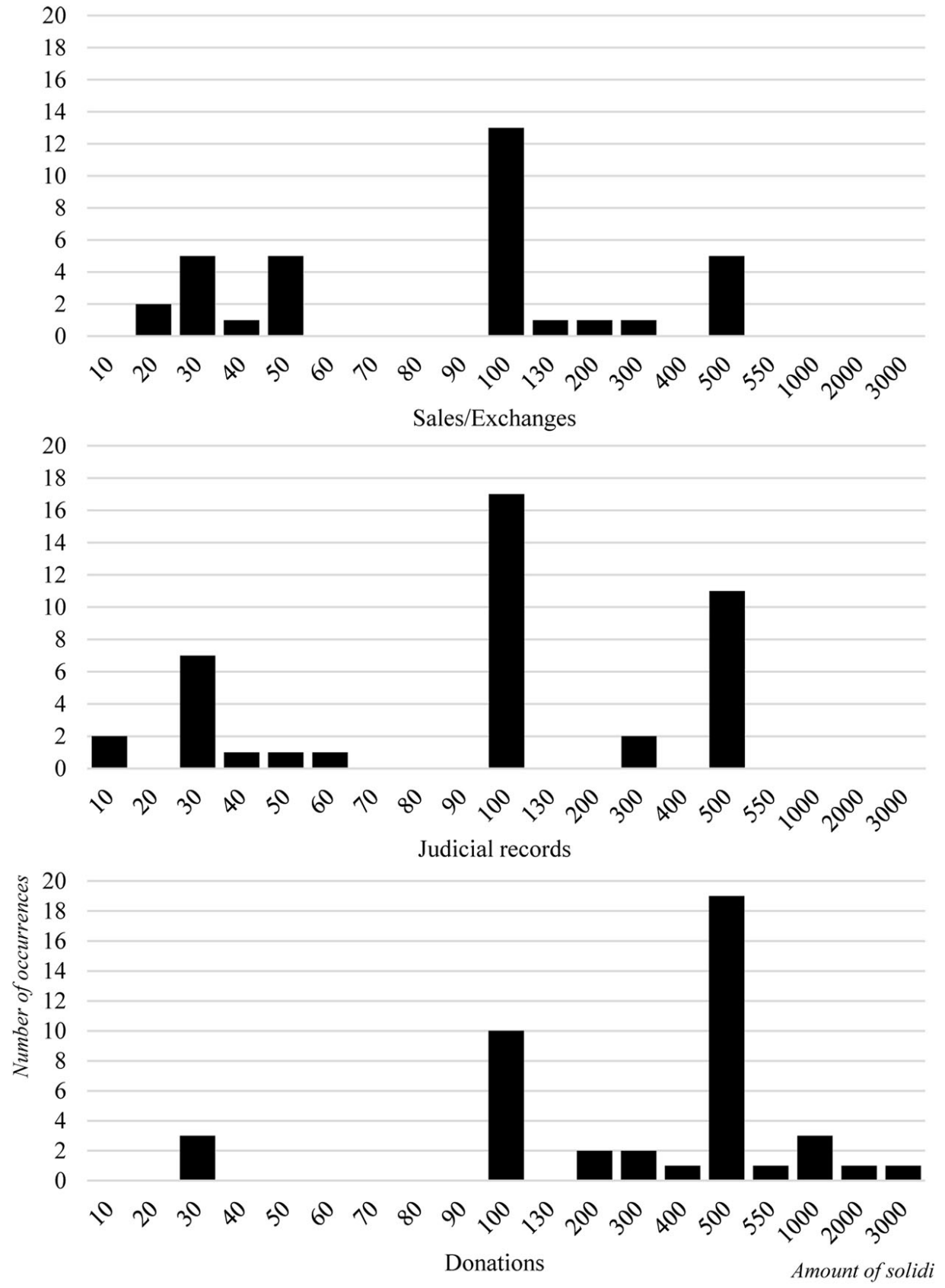

Figure 7. The value of monetary penalties in solidi by type of documentation. Source: Authors

\section{Social status and monetary penalties}

If the choice of gold weight or silver coinage depended on the nature of the business, then what about the specific amounts in each case? Could they reflect the value of the goods transferred, as has been suggested ${ }^{62}$ To demonstrate such a correspondence would require that the charters state both price and penalty in the same units. ${ }^{63}$ However, this

\footnotetext{
${ }^{62}$ Agúndez, 'Memoria y cultura', 886.

${ }^{63}$ Cf. Antonio Vives, La moneda castellana: discursos leídos ante la Real Academia de la Historia en la recepción pública (Madrid: Est. Tip. de la Viuda e Hijos de M. Tello, 1901), 8; Gautier-Dalché, 'Une histoire monétaire', 82-7; Sánchez-Albornoz, 'El precio de la vida', 812; Sánchez-Albornoz, 'Moneda de cambio', 880; José Ignacio San Vicente González de Aspuru, ‘Trueque, unidades de cuenta y circulación monetaria en Gasteiz (siglos VIII-XII d. C.)', in Arqueología e historia de una ciudad: los orígenes de
} 
only occurs in 23 cases throughout our entire corpus. These documents - mostly sales express both price and penalty in silver solidi, ${ }^{64}$ but there is no discernible correlation between the two values, as sanctions range from as low as 2.5 to as much as 55.5 times the price. The highest penalties (500 silver solidi) apply to prices ranging from 9 to 200 solidi ${ }^{65}$ while the more frequent sanction of 100 solidi applies to values from 3 to 26 solidi. This seems to rule out a correlation between the economic amounts at stake and their corresponding monetary sanctions.

If the monetary penalties defy interpretation as assessments of the actual value of the property it is necessary to explore another hypothesis, that they reflect the social position of the parties. ${ }^{66}$ The structure and dynamics of early medieval societies were profoundly informed by social difference, from legal status to less formal expressions of socio-economic rank. However, such mechanisms varied dramatically depending on the scale of the social systems and their evolution over time. In the post-Roman kingdoms, the main divide inherited from Antiquity between the free and unfree remained a powerful legal notion, but its impact in local contexts varied greatly between regions. ${ }^{67}$ Likewise, aristocratic status was very relevant in the highest political spheres, but was only of relative importance in local scenarios. In some instances, social difference could be formalised in a range of legal categories, as occurs most intricately in the Irish legal tradition and, to a lesser extent, in the early Anglo-Saxon kingdoms and other Germanic societies. ${ }^{68}$ However, in many areas the wide social distance between the unfree and the aristocracy was occupied by a spectrum of social positions with little or no legal definition. As Chris Wickham has put it, for much of the early Middle Ages village-level status was not closed at the top, and there was a continuum of free status up to the aristocracy. ${ }^{69}$ Aristocratic status ultimately tended to become more formally bounded, but when and to what extent this took place differed significantly from one place to another. In most contexts, social position was not a solid attribute that qualified a person or group; rather, it was highly relational, scale sensitive and performative. People defined their position according to those with whom they interacted. Someone could be prestigious and respected - even relatively wealthy - in a local context, but insignificant in the context of a royal assembly. ${ }^{70}$ Even inherited legal status had to be nurtured through actions performed in the presence of others. The formalities attached to property transfers were a context in which social status could not only be displayed, but also constructed before an audience. In this section, the term 'elite' is applied to people who held a prominent position in a given context, reserving the term 'aristocrat' for those who occupied the highest positions in the whole socio-political system.

In assessing the relationship between pecuniary penalties and status, it must be borne in mind that the Leonese charters operated within the legal framework inherited from the Visigothic period, even if this was often a vague environment that left much

Vitoria-Gasteiz, vol. 1, eds. Agustín Azkárate Garay-Olaun and José Luis Solaun Bustinza (Vitoria: Universidad del País Vasco, 2013), 367-8.

${ }^{64}$ Si40 (930), Si42 (931), Si68 (937), Si73 (939), Si81 (942), Si111 (949), Si127 (950), Si223 (964), Lii407 (968), Li428 (974), Liii635 (1003), Liii649 (1005), Sii405 (10199), OD130 (1021), Liii774 (1021), Liii792 (1022), Liii798 (1023), Liii828 (1026), OD197 (1032), Liv901 (1032), Sii448 (1036), OD219, (1036), Liv948 (1037).

${ }^{65}$ Liv901 (1032); Liii798 (1023).

${ }^{66}$ Agúndez, 'Memoria y cultura', 886.

${ }^{67}$ Chris Wickham, Framing the Early Middle Ages. Europe and the Mediterranean 400-800 (Oxford: Oxford University Press, 2005), 435 and ff. See more generally Rio, Slavery.

${ }^{68}$ Thomas M. Charles-Edwards, 'Críth Gablach and the Law of Status', Peritia 5 (1986): 53-73.

${ }^{69}$ Wickham, Framing the Early Middle Ages, 566.

${ }^{70}$ Wickham, Framing the Early Middle Ages, 153. 
space for innovation and adaptation (the use of silver coinage instead of gold in sanctions is precisely one such adaptation). ${ }^{71}$ Unlike some Germanic codes that contain a breakdown of legal status, often linked to a scale of compensation for homicide (wergild), nowhere in Visigothic law is there any systematic presentation of status. ${ }^{72}$ Nevertheless, references to status are pervasive, especially with regard to compensation for crimes. For example, in the Liber iudiciorum the main legal boundary was between free and unfree. If an unfree individual committed an offence, either he/she received physical punishment or his/her owner had to pay monetary compensation, or both. ${ }^{73}$ In contrast, free offenders were always sanctioned with monetary penalties, for example, 100 solidi for kidnapping and/or selling another freeman, and 300 solidi for homicide. ${ }^{74}$ The differences between aristocrats and ordinary freemen, though, are not so evident. Only in the latest redaction of the Liber, attributed to King Ervig (680-7), were aristocrats assigned a higher wergild of 500 solidi ${ }^{75}$ The social world that emerges from the Leonese charters is significantly different. ${ }^{76}$ The unfree appear only marginally, arguably not because there were not any, but because they were alien to the legal activities recorded in the documents. ${ }^{77}$ If there ever was a layer of charter production related to the unfree - as represented by the manumission charters that are so prominent in the Visigothic Formulae - such texts were

\footnotetext{
${ }^{71}$ Roger Collins, 'Sicut lex Gothorum continet: Law and Charter in Ninth- and Tenth-Century León and Catalonia', English Historical Review 100 (1985): 489-512; Roger Collins, 'Visigothic Law and Regional Custom in Disputes in Early Medieval Spain', in The Settlement of Disputes in Early Medieval Europe, eds. Wendy Davies and Paul Fouracre (Cambridge: Cambridge University Press, 1986), 85-104; Amancio Isla Frez, 'La pervivencia de la tradición legal visigótica en el reino asturleonés', Mélanges de la Casa de Velázquez 41, no. 2 (2011): 75-86; Barrett, 'Written and the World', 188-232. Specifically on the impact of Visigothic documentary practice on Leonese charters, see Miguel Calleja Puerta, 'Ecos de las Fórmulas visigóticas en la documentación altomedieval astur-leonesa', in Les formulaires. Compilation et circulation des modèles d'actes dans l'Europe médiévale et moderne, eds. Olivier Guyotjeannin, Laurent Morelle and Silio P. Scalfati (Paris: École nationale des chartes, 2016).

${ }^{72}$ On rank-graded compensations in so-called 'Germanic' codes, see generally Lisi Oliver, The Body Legal in Barbarian Law (Toronto: University of Toronto Press, 2011), 203-26.

${ }_{73}^{73}$ e.g.: Leg. Visig. VI, 4, 1; VI, 4, 3; VII, 2, 22.

${ }^{74}$ Leg. Visig., III, 3, 9; V, 4, 11; VI, 1, 2; VII, 3, 3; IX, 2, 3. In Leg. Visig., VII, 3, 3 the homicide of a freeman is compensated with 300 solidi, with no further explanation. Lesser injuries to freemen are likewise carefully graduated (Leg. Visig., VI, 4, 1; VI, 4, 3). In Leg. Visig., VI, 1, 2 there is a significant difference between the Reccesvinth recension, which puts the threshold at 300 solidi and the later version from Ervigius' time, which states 500 . Whether this is due to a general hardening of the penalties and/or a primary focus upon noble status in the latter version is an open question. Occasionally the laws indicate that payments for homicide could also be graduated according to the victim's age: Leg. Visig., 4, 16.

${ }^{75} \mathrm{Leg}$. Visig. VI, 1, 2. A difference is also made in the case of theft of church property (Leg. Visig., IX, 3, 3 ), where a monetary penalty of 100 solidi is prescribed for aristocratic offenders (honestiores) as opposed to 30 solidi for ordinary freemen (inferiores). Claudio Sánchez-Albornoz argued that this reflected an strengthening of aristocratic status in the late seventh century: En torno a los orígenes del feudalismo, II: Los árabes y el régimen prefeudal carolingio. Fuentes de la historia hispanomusulmana del siglo VIII. 2nd edn. (Buenos Aires: Editorial Universitaria de Buenos Aires, 1974), 153-61. However, some caution is needed when interpreting this passage, because by the time the extant manuscripts were copied the free/unfree distinction was less relevant, while that between aristocratic and non-aristocratic freemen had become more important: Marcos Fernández Ferreiro, Servos e escravos altomedievais no noroeste da Península Ibérica. Análisis del vocabulario de la dependencia medieval (La Coruña: Toxosoutos, 2010), and for a wider European perspective, see Rio, Slavery.

${ }^{76}$ Unfortunately, the only law code issued in the Leonese kingdom, the so-called Fuero de León, at the end of our period, is not explicit about social status: Gonzalo Martínez Díez, Legislación Conciliar del Reino Astur (718-910) y el Reino de León (910-1230) (León: Centro de Estudios e Investigación San Isidoro, 2009); Gonzalo Martínez Díez, 'La tradición manuscrita del fuero de León y del concilio de Coyanza', in El Reino de León en la alta edad media, vol. 2 (León: Centro de Estudios e Investigación San Isidoro, 1992), 117-88.

${ }^{77}$ Servi and ancillae are mentioned, to quote but two of a handful of instances, in Si328 (985), OD50 (98494). Such references are exceptional in León.
} 
unlikely to be preserved in monastic archives. ${ }^{78}$ The most visible distinction, then, was between aristocrats and ordinary freemen, but this left ample margin for social differentiation among the latter.

This can be explored through monetary penalties, but with some reservations. In Visigothic law compensation was graduated according to status: higher status offenders were punished with higher sums. By contrast, and even though the charters frequently foresee a wide social range of potential offenders, the penalties assigned to them for acting against the charter's dispositions are invariably the same, regardless of their status. For example, a grant made by two individuals named Iscam and Filauria to Sahagún stipulates one talent of gold as the fine for potential offenders, the list of whom includes their own siblings, cousins and others relatives, as well as strangers, whether magnates or low to medium ranking people. ${ }^{79}$ It is thus likely that what determined the quantity of the penalty was the status of the actors involved. This, however, is difficult to track at best, since in most cases status is less than clear, and, moreover, one would need to determine whose status was predominant, that of the grantor or the recipient.

A detailed, contextual characterisation of all actors is out of the question for a quantitative study like this one. We have therefore attempted a broad-brush approach that, while overlooking nuance, may suffice to test whether and how the actors' status is reflected in the monetary penalties. Firstly, actors have been classified according to their role in the document - in diplomatic terms - as either grantors or recipients. In donations the distinction is obvious. In sales, the seller has been considered the grantor and the buyer the recipient. In exchanges, which are admittedly less straightforward, the grantor has been considered the party who is said to initiate the operation. In records of dispute, we have classified as grantors those assuming obligations sanctioned with monetary penalties, which are usually the defeated or convicted parties. Likewise, in charters recording the appointment of sureties it is the latter who we have considered as grantors, for it was they who assumed the obligation. As for recipients, we have included both the victors of disputes, as well as the judging authorities when an obligation is assumed towards them. Secondly, we have defined four broad categories of status: major ecclesiastical institutions (MEI); local ecclesiastical institutions (LEI); aristocrats (A) and non-aristocratic laypeople (NAL). Clerics represent a grey zone, as they can act independently of their institutions or on behalf of them, without explicit statement. In this study they have been considered as representatives of ecclesiastical institutions, both major - as in the case of bishops - and local - as in the case of priests, though admittedly this could be further refined in future through contextual analysis of individual records. The line between lay aristocrats and non-aristocrats is equally difficult to draw. Here we have classified as aristocrats those individuals who are explicitly recognised as such in the charters, those whose noble status is well known from the literature and those whose estate, as detailed in the charter or as known from further contextual evidence, would correspond to that of an individual of high standing in the Leonese context, e.g. owners of several villae or properties in a relatively wide number of localities. All other lay parties have been classified as non-aristocrats. Once again, this could be refined through further contextual analysis.

\footnotetext{
${ }^{78}$ For León perhaps the only clear example is Liii894 (1031).

79 'de fratribus vel sororibus aut eorum filiis vel quibuslivet ex propinquis necnon de personis extraneis magnatis et infimis vel etiam mediocribus personis ... persolbat auri talentum a parte regis': Si164 (959).
} 

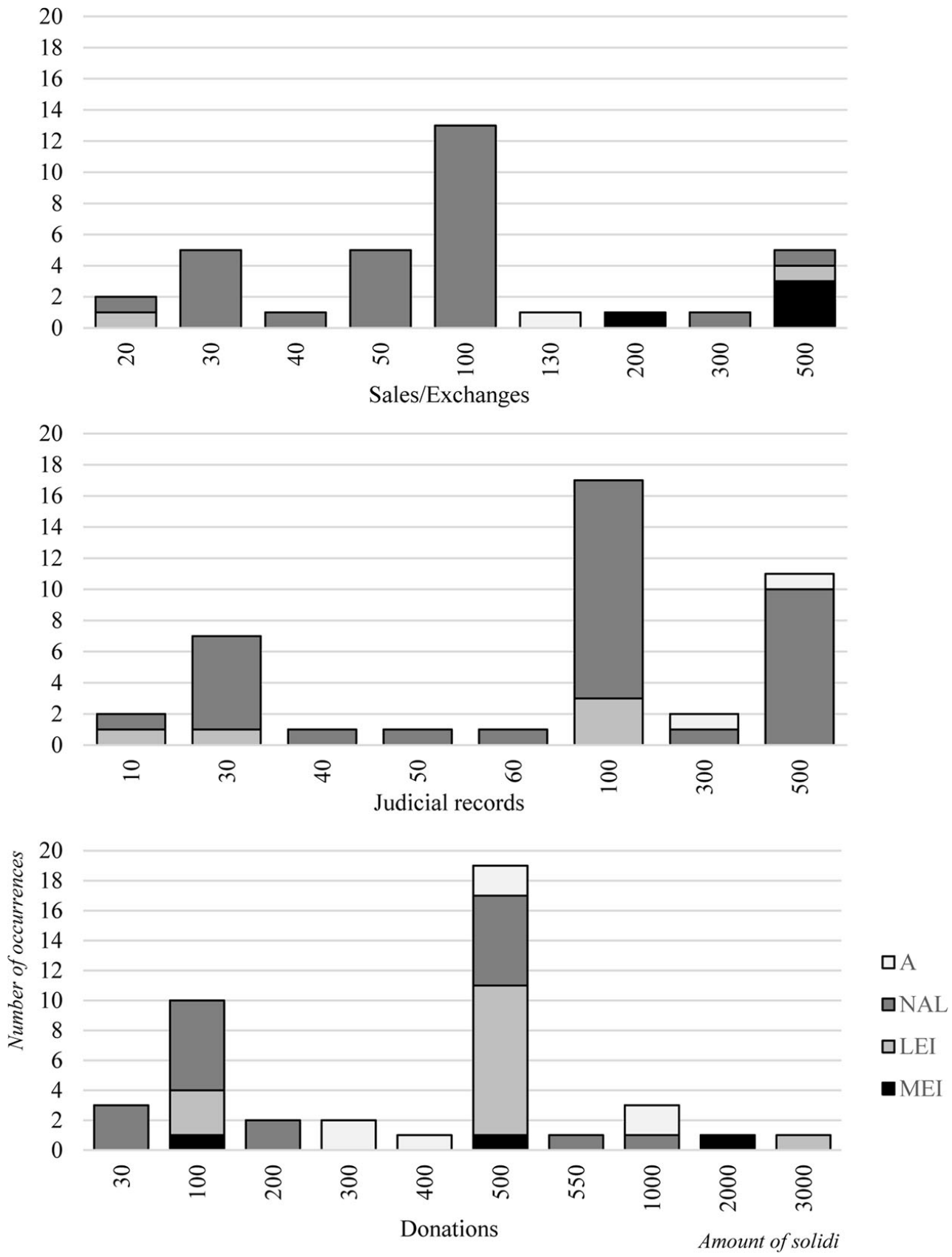

Figure 8. The value of monetary penalties in solidi by type of by type of document and by category of grantor. Source: Authors.

There is a clear contrast between grantors and recipients (Figures 8 and 9): most grantors are non-aristocrats while most recipients are either local or major ecclesiastical institutions. This is no surprise, given the inherent ecclesiastical bias of the record. This picture gains further nuance when broken down by type of legal business. Five out of six donations to aristocrats - three of which were in turn from aristocrats as well - have penalties of 300 solidi or more. Likewise, gifts to major churches tend to carry high sanctions regardless of the status of the donors. At the 500 solidi threshold, most donors were non-aristocrats: five laypeople and nine local churches out of a total of 16 cases. The same pattern repeats itself at the 100 solidi threshold. It seems that in donations, both the nature of the affair and the status of the recipients - most frequently high status parties - may have determined higher monetary penalties.

In sales and exchanges the overwhelming majority of grantors were non- 
aristocratic, while the recipients were mainly lay non-aristocrats and local churches. Transactions between low status actors exhibit the greatest consistency. First, all sales to local churches were made by non-aristocrats, with sanctions of 100 solidi or less. Second, all but one sale to lay commoners were made by other commoners, again with penalties of 100 solidi or less. Third, even sales to major churches by non-aristocrats tended to have sanctions of 100 solidi or less, although they did occasionally rise to as much as 500 solidi. Only when the vendors were aristocrats or major churches did monetary penalties reach higher levels. This strongly suggests that in sales/exchanges, monetary penalties tended to be generally lower, which may reflect the ordinary nature of the transaction, where the status of the grantor (vendor) was a determining factor.
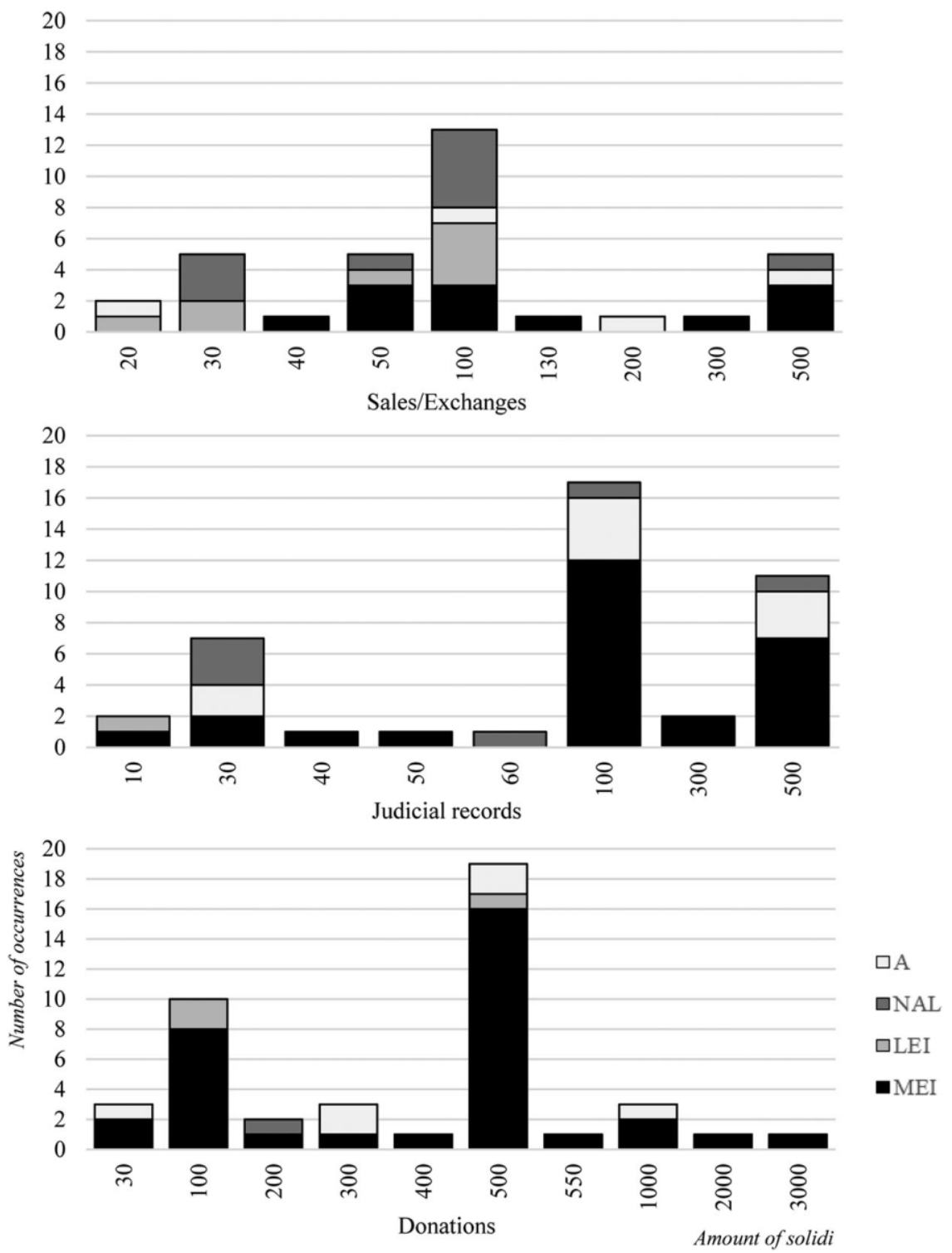

Figure 9. The value of monetary penalties in solidi by type of by type of document and by category of recipient. Source: Authors.

In records of disputes, the preference for sanctions of 30,100 or 500 solidi is much clearer than in the former groups. In 40 out of 42 extant cases, the grantors (mostly the defeated parties) were non-aristocrats or local churches. The 500 solidi group is particularly interesting: five out of seven cases correspond to lawsuits over the breach of conditions relating to an earlier donation to a major church, a kind of affair that typically entailed 
the highest penalties, as seen above. The penalties in these disputes could be thus interpreted as reinstatements of the original grants. ${ }^{80}$ This would leave us with the 30 and 100 solidi thresholds for a subset of largely non-aristocratic offenders, which suggests that in disputes the sanction was determined first by the nature of the offence, and then by the status of the offender.

\section{The meaning of the 100 solidi figure: weapons, horses and honour}

Across our corpus, the 500 solidi peak is clearly associated with the highest social spheres, but what could the equally prominent 100 solidi figure mean? Interestingly, 100 solidi is a figure that is repeated with relative frequency throughout the charters, beyond the realm of monetary penalties. Take, for instance, the widespread practice of countergifts. Some ordinary operations, like sales, were rounded off with an offering of bread and wine, or albaroc (>Sp. alboroque), to be consumed on the occasion. ${ }^{81}$ Exchange records, on the contrary, never include an albaroc, but one of the parties might add an extra, usually modest, payment, apparently with the aim of persuading 'the other party to go ahead with the transaction', as proposed by Wendy Davies. ${ }^{82}$ By contrast, donations were sometimes reciprocated by more valuable and solemn counter-gifts expressing the beneficiary's recognition of the donor ${ }^{83}$ In the charters these counter-gifts are said to be given in offertione, in roboratione or in honore, conceivably on the occasion when the transaction was formalised and/or the charter was made, and often consisted of prestige goods like clothing, arms or animals - most frequently horses or mules. ${ }^{84}$ Their monetary value is not always specified but, when stated, is invariably expressed in silver solidi. Davies has suggested that while low- and medium-value offertiones might have had a symbolic function as confirmation of the donation, higher ones may indeed come close to the value of the transfer and are better understood as price rather than as countergifts, and thus the transactions where they occur may be best regarded as sales. ${ }^{85}$

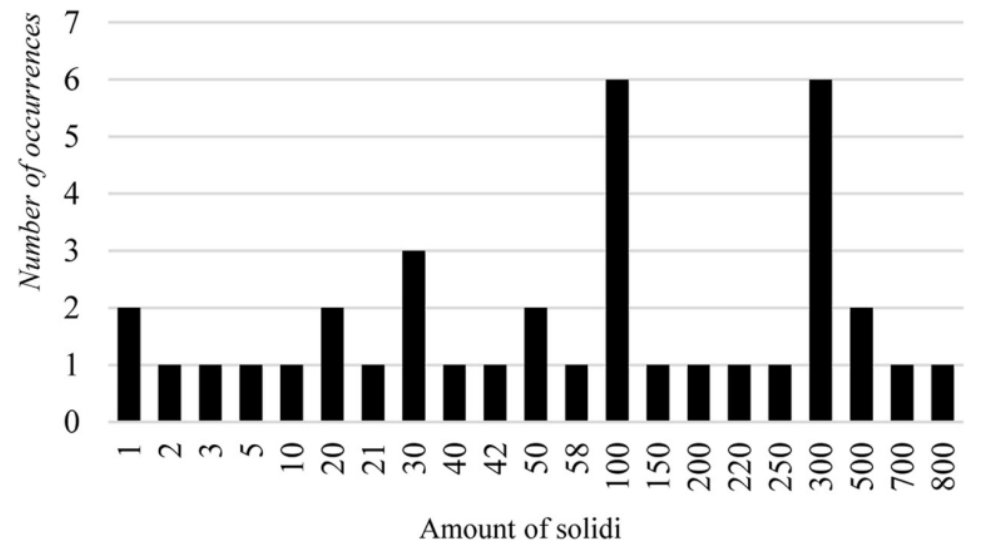

Figure 10. Value of offertiones in solidi, 900-1037. Source: Authors.

\footnotetext{
80 This is explicit in OD43 (997).

${ }^{81}$ The term alboroque is frequently found in later medieval documents and is used today in some regions of Spain to designate the food and drink provided at a funeral service.

${ }^{82}$ Davies, 'Exchange Charters', 482.

${ }^{83}$ They rarely occur in sales or exchanges. In fact, their appearance is grounds to suspect that there is a donation behind a sale or an exchange.

${ }^{84}$ Wendy Davies, 'Countergift in Tenth-Century Northern Iberia', in Early Medieval Spain. A Symposium, eds. Alan David Deyermond and Martin J. Ryan (London: Queen Mary College, University of London, 2010), 79-96, with a review of the literature.

${ }^{85}$ Davies, 'Countergift in Tenth-Century Northern Iberia', 85-7.
} 
However, the distribution of the values of offertiones in the Leonese charters yields a pattern by now familiar that suggests another reading (Figure 10). With some exceptions, ${ }^{86}$ the amounts tend to appear as round figures, in contrast to the detailed valuations of goods in sales. Under 100, they appear as multiples of 10, and thereafter as multiples of 100. There are peaks at 100 and 300 solidi. Grantors receiving offertiones worth less than 100 solidi were mostly non-aristocrats - 14 out of 17 cases; while those receiving offertiones of 100 solidi or more seem in almost all cases to be aristocrats - 18 out of 20 cases. However, the value of offertiones received by kings could vary widely, even from individuals or institutions of similar standing. ${ }^{87}$ This seems to indicate that there must be further subtle differences at play. The primary function of offertiones was to express recognition of the donor by the recipient. Therefore, they could relate to the former's honour, prestige and respectability. The significance of such recognition might have varied dramatically depending on actors and social contexts. While the king's standing would hardly be affected by a counter-gift, for local elites seeking promotion to be seen by their neighbours receiving a prestigious gift on a formal occasion could be a crucial move, particularly if the counter-gift 'overstated' their true position. In some transactions the counter-gift might indeed have been the real goal for middling elites, as a means to access valuable prestige goods that could be wielded as marks of distinction - a distinction already marked by the mere act of being seen receiving such a present. ${ }^{88}$ This would certainly justify in some cases giving a monastery a grant of roughly the same value as the offertio itself. This reasoning is reinforced in cases in which the grant/counter-gift can be seen to mark clientship towards the recipient. For instance, in 962 the husband and wife Fernando and María received a horse worth 100 solidi in confirmation for the grant they made to Abbess Doña Flámula as part of a profiliatio a transaction that probably signalled clientship. ${ }^{89}$ This would allow Fernando and María to display wealth, status and powerful patronage before their social connections, a position they may have already enjoyed for a while beforehand, or which they may have been in the process of constructing at the time.

There is a layer of transactions involving clerics in the lower echelons of the Church and parties which we would identify as non-aristocratic on the basis of the criteria detailed above, and which are formulated as sales but most probably worked as donations with a counter-gift. For example, in 978 a woman named Leocadia purchased a curtis and several lands and vineyards. ${ }^{90}$ The charter is formulated as a karta emptionis, but the price -100 solidi worth of silver and cloth - was given 'in confirmation of that charter of sale

\footnotetext{
${ }^{86}$ A very low sum is found in Liii651 (1005), where Xab Zuleimán gave a share in arable to the monastery of San Miguel de Vega and received in return just one solidus that was explicitly given a confirmanda scriptura testamenti.

${ }^{87}$ For example, kings received offertiones of varying value from individuals or institutions of similar standing in different cases. Compare Si261 (971); Liii767 (1019); OD196 (1031).

${ }^{88}$ On the role of offertiones as stimuli for the circulation of prestige objects, see Juan José Larrea, 'Du Tiraz de Cordoue aux montagnes du Nord. Le luxe en milieu rural dans l'Espagne chrétienne du haut moyen âge', in Objets sous contrainte. Circulation des objets et valeur des choses au moyen âge, eds. Laurent Feller and Ana Rodríguez (Paris: Publications de la Sorbonne, 2013), 43-61. On the value conferred on prestige objects as markers of social status and on the interests of elites in gaining access to them, see Wendy Davies, 'Notions of Wealth in the Charters of Ninth- and Tenth-Century Christian Iberia', in Les élites et la richesse au haut moyen âge, eds. J.P. Devroey, Laurent Feller and Régine Le Jan (Turnhout: Brepols, 2010), 265-84.

${ }^{89}$ Lii354 (962). A recent assessment of profilationes is to be found in Robert Portass, The Village World of Early Medieval Northern Spain: Local Community and the Land Market (Woodbridge: Boydell and Brewer for the Royal Historical Society, 2017), 85-6.

${ }^{90}$ Lii462 (978). Curtis identifies a holding consisting of a plot of land, sometimes enclosed, comprising one or various domestic buildings, ancillary structures, and cultivated areas, namely gardens and orchards.
} 
and testament ${ }^{91}$ and had a monetary penalty of one talent of gold, thus suggesting that it was actually a donation. Likewise, in 959 a man by the name of Agabio paid for a curtis in León with a sword worth 100 solidi. ${ }^{92}$ The 100 solidi figure could correspond either to a counter-gift or a price, but ultimately both of these options seem to have held a similar social meaning.

In the case of Fernando and María it is also interesting to note that the 100 solidi stood as the value of a horse. While the pricing of horses in sales and purchases was subject to a great deal of variation, and horses themselves were used as payment when purchasing other goods, if we chart the values that are attributed to them, where stated, peaks once again emerge at 100 and 300 solidi, thus matching the pattern of counter-gifts more widely (Figure 11). ${ }^{93}$ Whatever the sale price of an ordinary horse, a fine horse was a mark of status. Thus, in such cases, perhaps it was not so much that the horse was assessed at 100 solidi, but rather that it was equated to the social standing associated with the 100 solidi price tag. ${ }^{94}$ In local contexts, where social difference below aristocratic status was especially fluid and sensitive to gestures and rituals, such elements could have acted as formal, even enduring markers of an actor's social position or aspirations. For Fernando and María, the horse they received upon entering the clientship of abbess, Doña Flámula, perhaps functioned as a marker of their newly acquired social position. ${ }^{95}$

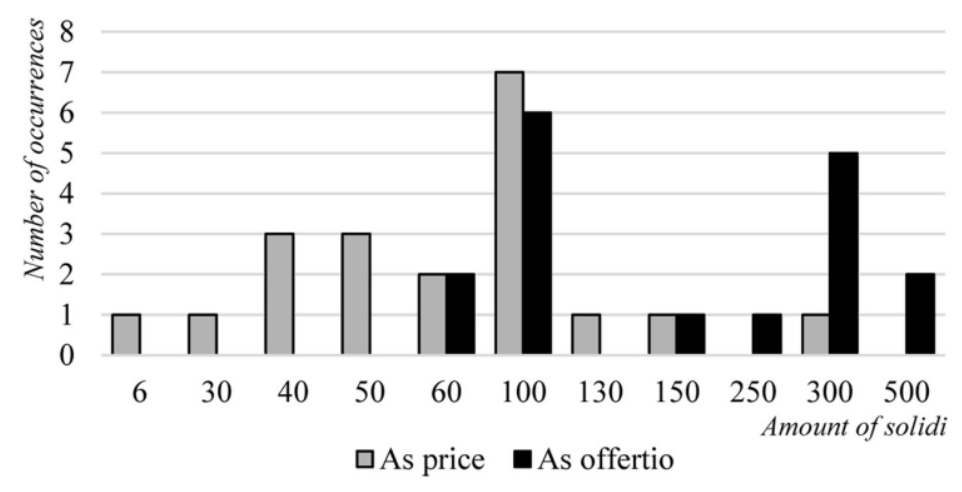

Figure 11. Value of horses in sales and in offertiones in solidi. Source: Authors.

This sort of substantive change in an actor's position can also be appreciated in records of suretyships, which represent one third of all dispute records with monetary penalties of 100 solidi -5 out of $14 .{ }^{96}$ In these charters those appointed surety are typically non-

\footnotetext{
91 'propter confirmationem kartulam uendiccionis uel testamento', Lii462 (978).

${ }^{92}$ Si166 (959).

93 e.g. Si278 (974); OD77 (1008); OD140 (1021); Liii798 (1023); Sii411 (1023); Liii890 (1031); OD216 (1035). On the price of horses in charters from north-western Iberia, see Sánchez-Albornoz, 'El precio de la vida', 819-23.

${ }^{94}$ On horses as markers of (male) status, see M. Isabel Pérez de Tudela y Velasco, Infanzones y caballeros. Su proyección en la esfera nobiliaria castellanoleonesa (s. IX-XIII) (Madrid: Universidad Complutense, 1979), 89-114; Michel Zimmermann, 'Arme de guerre, emblème social ou capital mobilier? Prolégomènes à une histoire du cheval dans la Catalogne', in Miscel-lània en homenatge al P. Agustí Altisent (Tarragona: Diputació de Tarragona, 1991), 119-58; Chris Wickham, 'Conclusion', in Languages of Gift, eds. Davies and Fouracre, 251-2.

${ }^{95}$ A similar point regarding weapons and horses received from monasteries is made for Bavaria by Matthew Innes, State and Society in the Early Middle Ages. The Middle Rhine Valley, 400-1000 (Cambridge: Cambridge University Press, 2000), 143-53.

96 Wendy Davies, 'On Suretyship in Tenth-Century Northern Iberia', in Scale and Scale Change in the Early Middle Ages: Exploring Landscape, Local Society and the World Beyond, eds. Julio Escalona and Andrew Reynolds (Turnhout: Brepols, 2011), 133-52.
} 
aristocrats acting on behalf of groups of actors, their kin, or even whole communities. ${ }^{97}$ They were chosen probably on the grounds of both personal prestige/reliability as well as economic soundness, and while they certainly took on risks in doing so, there were also rewards. Appearing as sureties at a public event would increase their reputation for trustworthiness, and reinforce an actual or potential position of leadership. ${ }^{98}$

The evidence has repeatedly indicated that 100 solidi - whether in coin or in kind - was a mark of social distinction among non-aristocrats in tenth-century León. Actors in these communities would thus have recognised the social implications of receiving a sword or a horse worth this sum. By the same token, we must assume that they would also have recognised the social implications of having one's deeds protected with a sanction of 100 solidi or a multiple thereof. Setting such a penalty, and reading it aloud before an audience and witnesses, were performative acts that could not merely express one's status, but even confer or reinforce it. Therefore, the charter was indeed 'an agent for the structuring of society'. ${ }^{99}$

\section{Conclusion}

Despite the apparent complexity of monetary penalties in medieval Leonese charters, quantitative analysis of this large but relatively homogeneous sample provides new insight into the rationale behind their use. Five aspects have been considered: the textual and legal sources upon which monetary sanctions drew; the types of units in which they were set; the type of legal business with which they were associated; the amounts at which they were set; and their relationship with the social actors involved. The same methodology can be extended to other collections in order to produce cross-regional comparisons, as well as to refine the procedures employed.

In tenth- and early eleventh-century charters from León, the use of monetary penalties - as with many other aspects of their diplomatic - drew heavily on the Visigothic legal heritage. ${ }^{100}$ However, this continuity was a dynamic one, where formulas and dispositions were updated and fine-tuned as needed, as seen in the shift to silver as money of account, the changes in the dating systems and the sidelining of diplomatic forms that had fallen out of common usage. ${ }^{101}$ Thus, monetary penalties were not mere antiquarian curiosities, but rather had contemporary meaning attached to them that had to make sense to both the actors and their audiences. They were highly symbolic and complex, situated at the crossroads of intersecting elements. First of all, the choice of units in silver coin or measures in gold placed the affair in one of two different conceptual spheres: gold for donations, especially to the Church, and coin for more mundane matters like sales, or for situations that demanded graduated expressions of value, if not proper assessment, as was often the case in judicial contexts.

Secondly, the group of charters with penalties in gold pounds or talents seems to defy any quantitative analysis of the highly variable amounts expressed. Given their close association with donations, particularly to the Church, a possible avenue for future research could be to treat them in relation to the spiritual sanctions with which they are usually associated. They might be seen as a hyperbolic statement of future punishment,

\footnotetext{
${ }^{97}$ See, for example, Sii366 (955); Si289 (977). By contrast, in two charters with a penalty of 30 solidi, the sureties are seen to cover for ordinary local people in very small-scale affairs or minor disputes: Lii477 (980); Liii784 (1022).

${ }^{98}$ On the public nature of judicial meetings at the local level, see Davies, Windows on Justice, 213-18.

${ }^{99}$ Bedos-Rezak, When Ego was Imago, 18.

100 Cf. Bowman, Shifting Landmarks, 61-9; Roger Collins, 'Sicut lex Gothorum continet'; Collins, 'Visigothic Law and Regional Custom'; Isla Frez, 'La pervivencia de la tradición'; and, more recently, Barrett, 'Written and the World', 188-96.

${ }^{101}$ Calleja Puerta, 'Ecos de las Fórmulas visigóticas'.
} 
much as the maledictions that aimed to safeguard Church property from sacrilegious violation.

Thirdly, for sanctions expressed in coin, the specific amount of the penalties did not depend upon a strictly economic rationale derived from the monetary value of the transaction recorded, but were meaningful nonetheless. Their connection to the actors' status emerges from the quantitative analysis, but the specifics of this connection are not so straightforward. For example, disputes about the violation of ecclesiastic property could be settled with extra-high sanctions that matched the higher consideration of pious donations, while other offences could bear penalties more in tune with the status of the intervening parties.

Perhaps most importantly, the present analysis has detected a significant layer of transactions involving major or local churches and what could be defined as local elites, or medium status laypeople, associated with monetary penalties on a scale of multiples or submultiples of 100, where 100 silver solidi has emerged as the most important peak. This group exhibits parallels with donations involving counter-gifts - especially of weapons or fine horses - and with records of sureties bearing the same 100 solidi sanction. Taken together, these texts can be read as written statements and public displays of social standing and patronage ties. As has been shown for many other local early medieval contexts, local elites probably constructed, maintained and enhanced their status within the fluid, ill formalised grey zone between the unfree and the aristocracy, even aiming to attain a qualitatively higher social position.

It is unlikely that any firm rules prescribed how monetary penalties in silver coinage were to be set in each case. They probably emerged from the negotiation of all factors involved, from the nature of the affair and its diplomatic wording to the existing or future interests and expectations of the actors. An audience familiar with this kind of business would have known how to interpret its components. It would have known, for instance, if a certain counter-gift was too high or too low for a donation, and if it reflected the position of the donor. It would have known whether a person whose deed was sanctioned with a 100 solidi penalty or higher would normally have been entitled to such an amount, or if, on the contrary, this amount signalled a change in his or her position regarding patronage and supporters. Even after taking exceptions into account, it is conscious choice, rather than scribal error or whim, that best explains the function and workings of monetary penalties, although much of their social significance has surely been irretrievably lost to us.

Ultimately, our study confirms the strong symbolic character of monetary penalties. As symbols, they were socially constructed and reflected widely shared social conceptions, though they were highly context sensitive. Monetary penalties were a relevant component of the mise-en-scène of property transfers and could be played with in diverse ways so that the same sanction would convey a different meaning in a local context than in the royal entourage. At the same time, the performative character of the transfers and their recording in charter format turned such sanctions into a powerful means of constructing social relations, especially in local, non-aristocratic contexts.

While this exercise in quantitative analysis has not revealed the existence of a uniformly observed set of norms governing sanction clauses - if in fact there ever was one - it has enabled us to scratch the surface of a whole world of extremely fluid and varying social relationships, notions and practices that informed their use. Further contextual analysis of specific cases carried out in the light of these findings may help to add nuance to our conclusions.

\section{Acknowledgements}


The authors are grateful for the comments and suggestions provided by several colleagues and friends who read previous versions of this article, especially Isabel Alfonso, Wendy Davies and Chris Wickham. They also thank the feedback from the anonymous reviewers that assessed the final version of the text.

\section{Funding}

This article was prepared with support from the FEDE project (HAR2013-47889-C3-2P), funded by the Programa Estatal de Investigación Científica y Técnica de Excelencia of the Spanish Government, and by the Ministerio de Economía y Competitividad of the Spanish Government under Research Project ref. HAR2016-7609 and under a Juan de la Cierva - Incorporación Postdoctoral Grant ref. IJCI-2015-23391. 